\title{
Güneydoğu Anadolu Bölgesinde tarımsal mekanizasyon düzeyinin 2010-2019 yıllarındaki değişimi ve gelecek yıllar için trend analizi ile belirlenmesi
}

The changes of agricultural mechanization level in Southeastern Anatolia Region between 2010-2019 and determination of the trends for the next decade using trend analysis

\author{
Hamza KUZU ${ }^{1}$ (D), Hayrettin KARADÖL ${ }^{1}$ (D) Ali AYBEK ${ }^{1}$ \\ ${ }^{1}$ Kahramanmaraş Sütçü Imam University, Faculty of Agriculture, Department of Biosystems Engineering, Kahramanmaraş, Turkey.
}

MAKALE BILGISI / ARTICLE INFO

Makale tarihçesi / Article history:

DOI: $10.37908 /$ mkutbd.767567

Geliş tarihi /Received:10.07.2020

Kabul tarihi/Accepted:22.09.2020

\section{Keywords:}

Agricultural mechanization level, Southeastern Anatolia Region, Trend analysis.

\footnotetext{
Corresponding author: Hamza KUZU

$\bowtie$ : kuzuhamza@hotmail.com
}

\section{Ö ZET / A B S TR A C T}

\begin{abstract}
Aims: It is aimed to determine the level of mechanization in the Southeastern Anatolia Region in order to make better production planning, increase productivity and create projections for the future in agricultural enterprises.

Methods and Results: In this study, mechanization level indicator values (kW ha-1, number of tractors 1000 ha $^{-1}$, ha tractor ${ }^{-1}$, machine tractor ${ }^{-1}$ ) in the provinces of Southeastern Anatolia Region in Turkey were determined for the years 2010-2019 and the trends in the $\mathrm{kW} \mathrm{ha}^{-1}$ value were predicted to using trend analysis for the years 2020-2030. The data were obtained from the Turkey Statistical Institute and the mechanization level indicators were calculated.

Conclusions: Throughout the region by years, $\mathrm{kW} \mathrm{ha}^{-1}$ and tractor $1000 \mathrm{ha}^{-}$ ${ }^{1}$ indicator values increased $\left(0.70-0.99 \mathrm{~kW} \mathrm{ha}^{-1} ; 17.45-24.63\right.$ tractor 1000 $\mathrm{ha}^{-1}$ ), but ha tractor ${ }^{-1}$ and machine tractor $^{-1}$ values decreased (57.29-40.60 ha tractor $^{-1}$; 5.17-5.04 machine tractor $\left.{ }^{-1}\right)$. The highest $\mathrm{kW} \mathrm{ha}^{-1}$ value was in the province of Adıyaman (1.81-2.47 kW ha-1) and the lowest was in Diyarbakır province (0.60-0.74 $\left.\mathrm{kW} \mathrm{ha}^{-1}\right)$. This indicator reached 0.70-0.99 $\mathrm{kW} \mathrm{ha-1}$ with an average increase of $3.70 \%$ in ten years throughout the region. An average increase of $2.47 \%$ was found in $\mathrm{kW} \mathrm{ha}^{-1}$ value for the period 2020-2030 for the whole region. This indicator was $2.2 \%$ greater than the average of Turkey. $\mathrm{kW} \mathrm{ha}^{-1}$ value for the whole region was estimated to be 1.02 in 2020, 1.16 in 2025 and 1.31 in 2030. The level of mechanization in the region has improved over the years, but this level of recovery rate was determined to be low.

Significance and Impact of the Study: Comprehensive identification of the level of agricultural mechanization on a regional/provincial basis with current data will be able to contribute to agricultural development plans and ensure that the correct decisions are made for the future. In this way, agricultural enterprises will be able to make healthier production planning, select optimum tractor and machine sizes, increase productivity and create projections for the future.
\end{abstract}

Atıf / Citation: Kuzu H, Karadöl H, Aybek A (2021) Güneydoğu Anadolu Bölgesinde tarımsal mekanizasyon düzeyinin 20102019 yıllarındaki değişimi ve gelecek yıllar için trend analizi ile belirlenmesi. MKU. Tar. Bil. Derg. 26(1) : 4162. DOI: $10.37908 /$ mkutbd.767567 


\section{GíRiş}

Tarım, artan nüfusu besleme, sanayiye hammadde sağlama, istihdam ve milli gelire katkısından dolayı, önemli bir sektördür (Sayın ve ark., 2015). Tarımsal mekanizasyon; ileri teknolojilerin uygulanmasını, ayrıca toprak, su, gübre, ilaç vd. girdilerin etkin kullanımını olanaklı kılarak tarımda verimliliği sağlayan önemli bir üretim aracıdır (Evcim ve ark., 2010) ve tarımsal üretim içerisinde toplam girdilerin yaklaşık yarısını oluşturmaktadır (Ruiyin ve ark., 1999; Landers, 2000). Bu nedenle kullanılan tarım makinalarının; işlev açısından işletmenin koşullarına ve traktöre uygun olmasının yanında, traktör ve makinaların, boyutu ve sayısı da önemlidir (Işık, 1988; Özpınar, 2001; Aybek ve Boz, 2006). Yaygın tarımsal mekanizasyon düzeyi gösterge değerleri; $\mathrm{kW}$ ha ${ }^{-1}$, traktör 1000 ha $^{-1}$, ha traktör $\mathrm{r}^{-1}$, makina traktör ${ }^{-1}$ 'dür (Koçtürk ve Avcıoğlu, 2007; Evcim ve ark., 2010; Korucu ve ark., 2015; Altuntaş, 2016; Yılmaz ve Sümer, 2018; Ulusoy ve ark., 2020). Bu gösterge değerlerinin "işletme Bazlı", "Ürün Bazlı", "Bölge Bazlı" yorumlanması hem değişimi ve gelişmeyi daha doğru yansıtabilecek (Ulusoy ve ark., 2020) hem de gelecekteki değerlendirmeler için bilimsel bir veri tabanı oluşumuna katkı sağlayabilecektir.

Güneydoğu Anadolu Bölgesi; Fırat ve Dicle havzaları ile yukarı Mezopotamya ovalarında yer alan 9 ili (Adıyaman, Batman, Diyarbakır, Gaziantep, Kilis, Mardin, Siirt, Şanlıurfa, Şırnak) kapsamaktadır. Temel hedefi, Güneydoğu Anadolu Bölgesi halkının gelir düzeyi ve hayat standardını yükselterek, bu bölge ile diğer bölgeler arasındaki gelişmişlik farkını ortadan kaldırmak, kırsal alandaki verimliliği ve istihdam imkanlarını artırarak, sosyal istikrar, ekonomik büyüme gibi milli kalkınma hedeflerine katkıda bulunmak olan Güneydoğu Anadolu Projesi (GAP), Türkiye'nin en büyük entegre bölgesel kalkınma projelerinden biridir. GAP çerçevesinde sürdürülebilir kalkınmanın temel bileşenleri ise sosyal, tarımsal, fiziksel, mekansal, çevresel sürdürülebilirlik ile ekonomik geçerlilik olarak ifade edilmiştir. Güneydoğu Anadolu Bölgesi'nin lokomotif sektörü tarımdır. Bölge'de 7.5 milyon ha alanının 3.2 milyon ha'ılık kısmı tarımsal faaliyetlere elverişlidir. Bilindiği gibi sulama GAP'ın en önemli altyapı yatırımlarından biridir. Yaklaşık 2.1 milyon ha'lık brüt alan sulama potansiyeline sahiptir. Bu alan Türkiye'nin ekonomik olarak sulanabilir arazisinin \%20'sine karşılık gelmektedir (Anonim, 2020a).

Güneydoğu Anadolu Bölgesinde son on yılda tarımı yapılan ürünlere ilişkin bilgiler (Anonim, 2020b) Çizelge 1 'de verilmiştir. Bölgede birçok tarımsal ürün yetiştirilebilmektedir. En fazla üretimi yapılan ürünler sırasıyla buğday, arpa, pamuk, mercimek, mısır, nohut, fiğ, yonca, ayçiçeği, aspir ve çeltik olmaktadır. Bölgede ayrıca meyve, sebze ve süs bitkileri üretimi de yapılabilmektedir (Çizelge 1 ).

Tarım bölgeleri; iklim, toprak, topoğrafya, bitki deseni vb. bakımından benzer özellikler göstermektedir. Bu nedenle tarım işletmelerinin; daha sağlıklı üretim planlaması yapması, verimliliği arttırması ve geleceğe yönelik projeksiyonlar oluşturması için mekanizasyon düzeyini ait olduğu bölgeye göre optimize etmeleri gerekmektedir.

Güneydoğu Anadolu Bölgesinde tarımsal mekanizasyon ve düzeyi ile ilgili birçok çalışma (Işık ve ark., 1995; Güler ve Yaylagül, 1997; Işık ve Atun, 1998; Bölükoğlu ve ark., 2001; Polat ve Sağlam, 2001; Benek, 2006; Sessiz ve ark., 2006; Vurarak ve ark., 2007; Gürsoy, 2012; Gürsoy, 2013; Bilim ve ark., 2014; Sağlam ve ark., 2014; Sağlam ve Çevik, 2014; Evcim ve ark., 2015; Korucu ve ark., 2015; Malaslı ve ark., 2015; Özel, 2015; Bozkurt ve Aybek, 2016; Altuntaş, 2016; Dağ, 2018; Solmaz ve ark., 2019) yapılmıştır. Yapılan çalışmalar bölgenin bazı illerini veya sadece genelini ya da belli yılları içerdiğinden bölgeyi tüm detayları ile sağlıklı olarak yansıtmamaktadır.

Tarımsal mekanizasyon düzeyinin artması, tarımsal üretimin gelişmesinde ve diğer üretim teknolojilerinin etkin bir şekilde uygulanması açısından önemlidir (Altıkat ve Çelik, 2009). Bu nedenle tarımsal mekanizasyon düzeyinin bölgesel/iller bazında kapsamlı olarak güncel verilerle ortaya konulması, mekanizasyon uygulama yoğunlukları ve etkinlikleri açısından karşılaştırma yapılmasını ve geleceğe yönelik doğru kararların alınmasını sağlayabilecektir (Say ve ark., 2010; Bayram ve Altuntaş, 2016). Bu veriler ve karşılaştırmalar sayesinde daha sağlıklı tarımsal yatırım ve planlamalar yapılarak işletmelerin üretim karlılığı, rekabet gücü, optimum işletme büyüklükleri sağlanabilir. Bu çalışmada Güneydoğu Anadolu Bölgesinin iller bazında tarımsal mekanizasyon düzeyinin 2010-2019 yıllarındaki değişimi ve gelecek yıllar için trend analizi ile belirlenmesi ve değerlendirilmesi amaçlanmıştır. TÜik verilerinden, mekanizasyon düzeyi gösterge değerleri ( $\mathrm{kW} \mathrm{ha}^{-1}$, traktör $1000 \mathrm{ha}^{-1}$, ha traktör ${ }^{-1}$, makina traktör ${ }^{-1}$ ) hesaplanmış, yıllar içerisinde mekanizasyon düzeyinde meydana gelen değişimler belirlenmiş ve trend (eğilim) analizi ile gelecek yıllar (2020-2030) için kW ha-1 gösterge değerleri tahmin edilmiş ve değerlendirilmeler yapılmıştır. Çalışmanın, ele alınan bölgenin mekanizasyon planlamalarına katkı sağlayacağı beklenmektedir. 
Çizelge 1. Güneydoğu Anadolu Bölgesinde son on yılda tarımı yapılan ürünlere ilişkin bilgiler

Table 1. Information about products growned in the Southeastern Anatolia region in the last decade

Ürünler ve ekiliş alanları (x1000 ha)

\begin{tabular}{|c|c|c|c|c|c|c|c|c|c|c|c|c|c|c|c|c|}
\hline$\frac{\frac{1}{\bar{t}}}{\overline{\bar{\nu}}}$ & 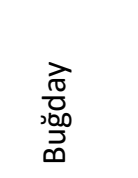 & 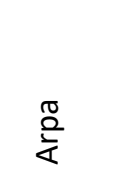 & $\begin{array}{l}\text { 兰 } \\
\stackrel{E}{\widetilde{\Xi}} \\
\alpha\end{array}$ & 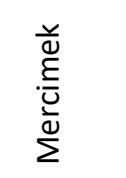 & $\stackrel{\frac{\grave{M}}{\Sigma}}{\Sigma}$ & $\begin{array}{l}\frac{n}{2} \\
\frac{1}{0} \\
\frac{1}{2}\end{array}$ & 2000 & 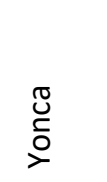 & 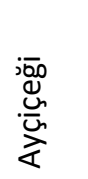 & $\frac{\grave{\bar{a}}}{\frac{\bar{n}}{4}}$ & 姜 & 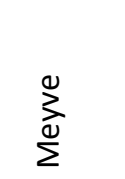 & $\frac{N}{N}$ & 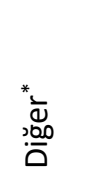 & 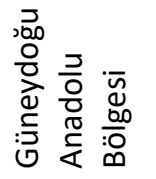 & : \\
\hline 2010 & 1306.82 & 449.62 & 287.89 & 207.13 & 139.63 & 54.30 & 22.81 & 6.83 & 6.63 & 6.62 & 5.91 & 430.38 & 72.66 & 25.53 & 3022.77 & 20145.18 \\
\hline 2011 & 1297.46 & 395.64 & 313.92 & 187.39 & 146.49 & 44.39 & 18.31 & 7.04 & 4.83 & 4.21 & 2.67 & 449.43 & 63.03 & 16.51 & 2951.31 & 19592.34 \\
\hline 2012 & 1204.33 & 391.67 & 302.27 & 208.15 & 183.44 & 38.60 & 22.56 & 10.17 & 4.84 & 3.36 & 3.60 & 510.17 & 69.18 & 22.97 & 2975.30 & 19491.07 \\
\hline 2013 & 1273.98 & 423.50 & 278.94 & 251.60 & 206.23 & 39.93 & 17.18 & 9.47 & 6.16 & 1.08 & 3.49 & 514.24 & 74.54 & 25.06 & 3125.40 & 19653.42 \\
\hline 2014 & 1277.61 & 442.61 & 289.47 & 225.22 & 196.56 & 36.94 & 8.07 & 10.70 & 4.28 & 0.55 & 2.13 & 511.15 & 73.94 & 23.41 & 3102.64 & 19828.20 \\
\hline 2015 & 1289.10 & 440.87 & 264.52 & 201.00 & 221.36 & 33.11 & 8.35 & 10.77 & 8.02 & 1.00 & 2.36 & 520.99 & 72.66 & 21.09 & 3095.21 & 19815.04 \\
\hline 2016 & 1206.87 & 412.62 & 238.33 & 227.92 & 190.90 & 32.49 & 8.96 & 10.04 & 6.99 & 0.44 & 1.97 & 546.39 & 71.15 & 24.10 & 2979.15 & 19708.00 \\
\hline 2017 & 1181.18 & 359.50 & 293.17 & 256.73 & 171.89 & 35.70 & 9.59 & 8.44 & 7.73 & 0.56 & 2.10 & 556.69 & 68.10 & 24.44 & 2975.80 & 19644.19 \\
\hline 2018 & 1102.82 & 352.82 & 312.78 & 227.50 & 128.85 & 62.57 & 8.75 & 7.83 & 6.54 & 0.59 & 2.35 & 588.69 & 68.21 & 28.42 & 2898.71 & 19662.04 \\
\hline 2019 & 998.95 & 356.08 & 288.91 & 222.84 & 162.62 & 77.27 & 9.18 & 13.11 & 8.24 & 0.01 & 2.07 & 597.92 & 68.03 & 26.96 & 2832.19 & 19702.30 \\
\hline
\end{tabular}

* Diğer ile belirtilen grupta; adaçayı, bakla, bezelye, börülce, burçak, çavdar, çemen otu, darı, fasulye, gül, haşhaş, ısırgan otu, italyan çimi, kaplıca, kenevir, keten, kolza, korunga, kuş yemi, lavanta, melisa, mürdümük, patates, sorgum, soya fasulyesi, susam, şeker kamışı, şeker pancarı, şerbetçiotu kozalağı, triticale, tütün, üçgül, yem şalgamı, yer elması, yerfıstığı, yulaf, anemon, altınbaşak, fresia, gerbera, glayöl, gül, gypsohilla, iris, karanfil, kasımpatı, lale, lisianthus, nergis, orkide, statice, sümbül, şebboy, zambak, çiçek soğanları, iç ve dış mekan süs bitkileri ile diğer çiçek ve çiçek koncaları gibi tahıllar, bitkiler ve süs bitkileri yer almaktadır. 


\section{MATERYAL ve YÖNTEM}

Çalışmada, ele alınan Güneydoğu Anadolu Bölgesinin tarımsal mekanizasyon düzeyi gösterge değerlerinin belirlenmesi için veriler (tarımsal üretim alanları, traktör sayıları, traktör güçleri ve tarım alet-makina sayıları), Türkiye İstatistik Kurumu (TÜiK) kayıtlarından alınmıştır (Anonim, 2020b; Anonim, 2020c). Veriler, son on yıllık (2010-2019) dönemi kapsayıp, bölgeyi oluşturan illere (Adıyaman, Batman, Diyarbakır, Gaziantep, Kilis, Mardin, Siirt, Şanlıurfa, Şırnak) göre oluşturulmuştur.

Tarım alanları, ekili alanların ve nadas alanlarının toplamı olarak alınmıştır. Tarım alet ve makina sayıları Çizelge 2 'de verilen alet ve makinalar dikkate alınarak belirlenmiştir. Traktör sayıları belirlenirken sadece tekerlekli traktörler dikkate alınmıştır. Traktörler tek akslı ve çift akslı olarak gruplandırılmış, her grup içerisinde de güç değerlerine göre alınarak (Çizelge 3) sınıflandırmalar ve hesaplamalar yapılmıştır. BG olan traktör güç değerleri, 0.736 ile çarpılarak $\mathrm{kW}$ değerine dönüştürülmüştür.

Bölgedeki iller bazında 2010-2019 yıllarına göre belirlenen; toplam tarım alanları Çizelge 4 'de, toplam traktör sayıları Çizelge $5^{\prime}$ de, ortalama traktör güç değerleri Çizelge $6^{\prime} \mathrm{da}$, toplam traktör güç değerleri Çizelge 7'de ve toplam tarım alet-makina sayıları ise Çizelge 8'de verilmiştir.

Çizelge 2. Hesaplamalarda kullanılan tarım alet-makina isimleri

Table 2. Agricultural equipment-machine names used in calculations

\begin{tabular}{lll}
\hline Kulaklı traktör pulluğu & Kombine hububat ekim makinesi & Yerfıstığı hasat makinesi \\
Kulaklı anız pulluğu & Pnömatik ekim makinesi & Yerfıstığı harman makinesi \\
Ark açma pulluğu & Fide dikim makinesi & Traktörle çekilen çayır biçme makinesi \\
Dip kazan (subsoiler) & Patates dikim makinesi & Ot tırmığı \\
Diskli anız pulluğu (vanvey) & Çapa makinesi & Balya makinesi \\
Diskli tırmık (diskaro) & Kimyevi gübre dağıtma makinesi & Ot silaj makinesi \\
Diskli traktör pulluğu & Çiftlik gübresi dağıtma makinesi & Mısır silaj makinesi \\
Dişli tırmık & Kuyruk milinden hareketli pülverizatör & Sap döver ve harman makinesi (batöz) \\
Kombikürüm (karma tırmık) & Atomizör & Sap toplamalı saman yapma makinesi \\
Kültivatör & Motorlu pülverizatör & Römork (tarım arabası) \\
Merdane & Biçer bağlar makinesi & Meyve hasat makineleri \\
Toprak frezesi (rotovatör) & Orak makinesi & Fındık harman makinesi \\
Sap parçalama makinesi & Mısır hasat makinesi & Su tankeri (tarımda kullanılan) \\
Set yapma makinesi & Pancar sökme makinesi & Taş toplama makinesi \\
Anıza ekim makinesi & Kombine pancar hasat makinesi & Toprak burgusu \\
Traktörle çekilen hububat ekim makinesi & Patates sökme makinesi & Toprak tesviye makinesi \\
Üniversal ekim makinesi (mekanik) & Kombine patates hasat makinesi & Yem dağıtıcı römork
\end{tabular}

Çizelge 3. Traktörlerin güç hesaplamalarında kullanılan ortalama güç değerleri

Table 3. Average power values used in power calculations of tractors

\begin{tabular}{lc}
\hline Traktör grubu & Ortalama güç (BG) \\
\hline Tek akslı (1-5 BG) & 3.0 \\
Tek akslı (5 BG'den fazla) & 7.5 \\
Tek akslı (1-10 BG) & 5.5 \\
Tek akslı (11-24 BG) & 17.5 \\
Tek akslı (25-34 BG) & 29.5 \\
Tek akslı (35-50 BG) & 42.5 \\
Tek akslı (51-70 BG) & 60.5 \\
Tek akslı (70 BG'den fazla) & 85
\end{tabular}


Mekanizasyon düzeyinin belirlenmesinde; birim alana düşen traktör gücü $\left(\mathrm{kW} \mathrm{ha}{ }^{-1}\right), 1000$ ha alana düşen traktör sayısı (traktör $1000 \mathrm{ha}^{-1}$ ), bir traktöre düşen toplam alan (ha traktör-1) ve bir traktöre düşen makina sayısı (makina traktör ${ }^{-1}$ ) göstergeleri dikkate alınmıştır. Mekanizasyon düzeyi gösterge değerlerinin hesaplanmasında Çizelge 4-8 bilgilerinden yararlanılmıştır. Gelecek yıllar (2020-2030) için mekanizasyon düzeyi $\left(\mathrm{kW} \mathrm{ha}^{-1}\right)$ gösterge değerinin tahmin edilmesinde trend analizi kullanılmıştır. Trend (eğilim) analizi, bir zaman serisinin uzun dönemdeki ana eğilimi olarak tanımlanan eğilimin bir doğru veya bir eğri ile ifade edilmesidir (Yavuz, 2016). Bu analiz genel olarak, çizgiler veya yüzeylerle temsil edilebilen eğilimlerin tanınması ve ölçülmesiyle ilgilenmektedir (Allen, 1964; Maxwell ve Delaney, 2004). Bununla birlikte, zaman serilerinin uzun dönemde kararlı alçalma ya da yükselme şeklinde bir eğilime de sahip olabilecekleri bilinmektedir (Newbold, 2000). Trendin tahmini, en küçük kareler yöntemi, hareketli ortalama ve yarıyı ortalamalar yöntemi ile yapılabilmektedir (Abdikoğlu, 2019). Bu çalışmada trend eğrisinin denklemini bulmak için en küçük kareler yöntemi kullanılmıştır. Trend eğrisinin denklemini bulmak için en küçük kareler yönteminin farklı denklem türlerinin incelenmesi gerekmektedir (Witt ve Witt, 1992). Zaman serisine en uygun düşen fonksiyonun belirlenebilmesi için kullanılan fonksiyon tipleri sırasıyla (doğrusal, logaritmik, üssel ve polinom eğilimi) Eşitlik 1, 2, 3 ve 4'te verilmiştir (Semerci ve Özer, 2011).

$y=m x+b$

$y=c \ln x+b$

$y=c x^{b}$

$y=b+c_{1} x+c_{2} x^{2}+c_{3} x^{3}+\cdots+c_{6} x^{6}$

Eşitliklerde; $m$ eğim, $a, b, c, c_{1} \ldots c_{6}$ sabitlerdir.

İncelenen denklem türleri arasında determinasyon katsayısı $\left(R^{2}\right)$ en yüksek olan denklem türünün tüm testler için doğrusal trend denklemi olduğu belirlenmiştir. Elde edilen veriler çizelgelere ve grafiklere aktarılarak değerlendirilmiştir.

\section{BULGULAR ve TARTIŞMA}

Son on yılda ortalama olarak bölge genelinde; işlenen tarım alanlarında (Çizelge 4) azalma görülürken, traktör sayılarında (Çizelge 5), ortalama traktör güç değerlerinde
(Çizelge 6), toplam traktör güç değerlerinde (Çizelge 7) ve tarım alet-makina sayılarında (Çizelge 8 ) ise artış görülmektedir. On yıllık zaman diliminde, bölge illerinin; toplam tarım alanlarında Gaziantep, Şırnak ve Kilis'te artış diğer illerde azalma (Çizelge 4), toplam traktör sayılarında Batman ve Şırnak'ta azalma diğer illerde artış (Çizelge 5), ortalama traktör güç değerlerinde Adıyaman, Batman, Gaziantep ve Siirt'te azalma diğer illerde artış (Çizelge 6) ve toplam tarım alet-makina sayılarında ise tüm illerde artış (Çizelge 8) olmuştur.

Güneydoğu Anadolu Bölgesi'nin iller bazında; 2010-2019 yıllarındaki mekanizasyon düzeyi gösterge değerleri Çizelge 9-12'de, bu gösterge değerlerinin değişimi Şekil 1-4'te, gelecek yıllar (2020-2030) için trend analizi ile belirlenen toplam üretim alanına düşen traktör gücü $(\mathrm{kW}$ $h^{-1}$ ) değerleri Çizelge $13^{\prime}$ te ve değişimi ise Şekil 5'te verilmiştir.

2010-2019 yılları arasında, birim alana düşen traktör gücü ( $\mathrm{kW} \mathrm{ha-1}$ ) değeri; bölgenin tüm illerinde ve bölge genelinde yıllara göre artış göstermiş ve en yüksek değerler Adıyaman ilinde (1.81-2.47 kW ha-1), en düşük değerler ise Diyarbakır ilinde $\left(0.60-0.74 \mathrm{~kW} \mathrm{ha}^{-1}\right)$ görülmektedir. Bölge genelinde ise $\mathrm{kW} \mathrm{ha}^{-1}$ değeri son on yılda ortalama \%3.70 artış göstermiş ve $0.70-0.99 \mathrm{~kW}$ ha ${ }^{1}$ olmaktadır. Bölgede, Adıyaman hariç tüm illerin kW ha 1 olarak mekanizasyon düzeyi değeri Türkiye ortalamasının altında görülmektedir (Çizelge 9, Şekil 1). Bölge ve illerin, işlenen alan başına düşen traktör gücü $\left(\mathrm{kW} \mathrm{ha}^{-1}\right)$ gösterge değerlerinin yıllara göre giderek artması, yıllara göre traktör sayısı (Çizelge 5) ve güç değerlerinin (Çizelge 6-7) artmasından ve ekonomik ömrünü dolduran traktörlerin yerine daha yüksek güçlü traktörlerin satın alınması ile açıklanabilir.

Son on yılda (2010-2019), traktör 1000 ha $^{-1}$ değeri; tüm bölge illerinde ve bölge genelinde yıllara göre artmıştır (Şekil 2). Bölgenin on yıllık ortalama artış değeri (\%3.68) Türkiye ortalamasından (\%2.91) daha yüksek olmuştur (Çizelge 10). Traktör 1000 ha $^{-1}$ değerinin artması; yıllara göre traktör sayısının artması (Çizelge 5) ve işlenen tarım alanlarının azalması (Çizelge 4) ile açıklanabilir.

2010-2019 yılları arasında, ha traktör-1 değeri; bölgenin tüm illerinde yıllara göre azalmıştır (Şekil 3). Bölgenin on yıllık ortalama azalma değeri (-\%3.99) Türkiye'nin ortalama değerinden daha yüksek (-\%3.01) olmuştur (Çizelge 11). ha traktör $^{-1}$ değerindeki azalma, mekanizasyon düzeyinin artış göstermesi ya da iyileşme sağlaması şeklinde yorumlanabilir. 
Çizelge 4. Güneydoğu Anadolu Bölgesi illerinin 2010-2019 yıllarındaki toplam tarım alanları (ha) Table 4. Total agricultural areas (ha) of the Southeastern Anatolia Region provinces between 2010-2019

\begin{tabular}{|c|c|c|c|c|c|c|c|c|c|c|c|c|c|c|c|c|c|c|c|c|c|c|}
\hline \multirow[b]{2}{*}{$\frac{\grave{i}}{\bar{\equiv}}$} & \multicolumn{2}{|c|}{ 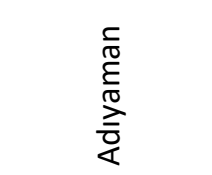 } & \multicolumn{2}{|c|}{ 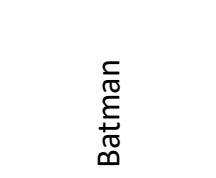 } & \multicolumn{2}{|c|}{$\begin{array}{l}\frac{1}{\frac{1}{5}} \\
\frac{0}{0} \\
\frac{0}{0} \\
\stackrel{0}{0}\end{array}$} & \multicolumn{2}{|c|}{$\begin{array}{l}\stackrel{0}{\Phi} \\
\stackrel{ \pm}{\frac{1}{N}} \\
. \frac{\pi}{N} \\
\mathbb{0} \\
0\end{array}$} & \multicolumn{4}{|c|}{ 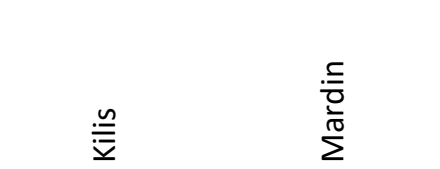 } & \multicolumn{2}{|c|}{ 涪 } & \multicolumn{2}{|c|}{ 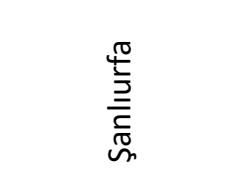 } & \multicolumn{2}{|c|}{ 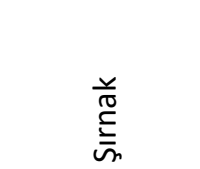 } & \multicolumn{2}{|c|}{ 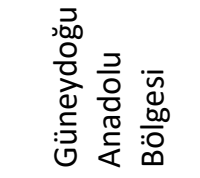 } & \multicolumn{2}{|l|}{ 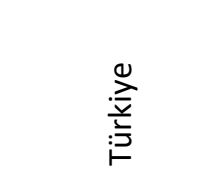 } \\
\hline & 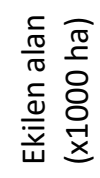 & $\begin{array}{l}\frac{y}{\bar{t}} \\
\text { do }\end{array}$ & 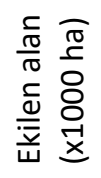 & 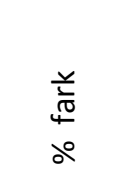 & 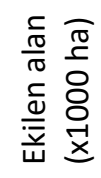 & 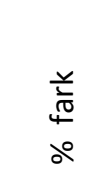 & 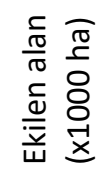 & 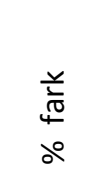 & 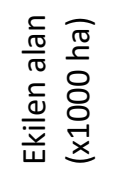 & 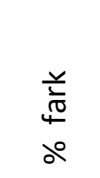 & 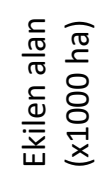 & 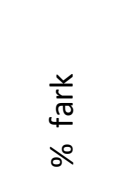 & 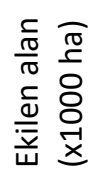 & 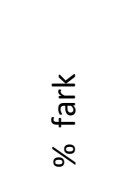 & 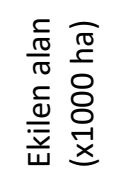 & 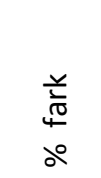 & 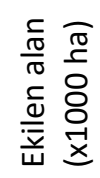 & 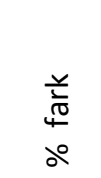 & 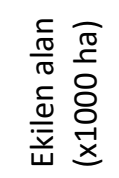 & 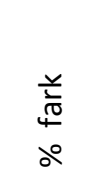 & 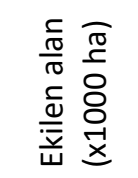 & 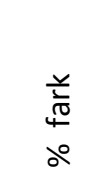 \\
\hline 2010 & 246.3 & & 125.5 & & 611.3 & & 308.9 & & 99.9 & & 360.8 & & 96.6 & & 1259.1 & & 103.8 & & 3212.3 & & 24394.2 & \\
\hline 2011 & 239.9 & -2.60 & 129.0 & 2.74 & 599.1 & -1.99 & 309.6 & 0.25 & 99.5 & -0.40 & 322.4 & -10.64 & 83.6 & -13.41 & 1144.4 & -9.11 & 100.7 & -3.02 & 3028.3 & -6.08 & 23613.8 & -3.31 \\
\hline 2012 & 234.2 & -2.40 & 124.3 & -3.65 & 570.8 & -4.72 & 367.0 & 18.53 & 103.1 & 3.64 & 322.5 & 0.03 & 91.5 & 9.37 & 1072.0 & -6.33 & 95.3 & -5.31 & 2980.7 & -1.60 & 23782.0 & 0.71 \\
\hline 2013 & 240.8 & 2.84 & 117.8 & -5.24 & 601.5 & 5.37 & 361.7 & -1.44 & 105.3 & 2.11 & 322.4 & -0.04 & 81.7 & -10.69 & 1220.0 & 13.81 & 101.3 & 6.29 & 3152.6 & 5.45 & 23805.5 & 0.10 \\
\hline 2014 & 240.3 & -0.21 & 115.2 & -2.21 & 614.7 & 2.19 & 361.6 & -0.04 & 105.4 & 0.07 & 331.8 & 2.90 & 78.4 & -4.05 & 1181.6 & -3.15 & 100.2 & -1.08 & 3129.1 & -0.75 & 23940.7 & 0.56 \\
\hline 2015 & 239.8 & -0.20 & 112.0 & -2.70 & 606.0 & -1.41 & 358.9 & -0.76 & 105.0 & -0.33 & 328.2 & -1.07 & 84.9 & 8.36 & 1181.5 & -0.01 & 94.5 & -5.74 & 3110.9 & -0.58 & 23933.6 & -0.03 \\
\hline 2016 & 240.8 & 0.42 & 101.6 & -9.33 & 589.8 & -2.67 & 353.9 & -1.39 & 104.6 & -0.42 & 313.8 & -4.40 & 88.8 & 4.48 & 1155.2 & -2.22 & 77.9 & -17.55 & 3026.3 & -2.79 & 23711.2 & -0.94 \\
\hline 2017 & 234.8 & -2.52 & 91.1 & -10.31 & 575.2 & -2.47 & 351.5 & -0.68 & 102.6 & -1.90 & 313.1 & -0.21 & 83.6 & -5.80 & 1108.0 & -4.09 & 106.8 & 37.08 & 2966.6 & -2.01 & 23346.6 & -1.56 \\
\hline 2018 & 234.3 & -0.18 & 93.8 & 2.92 & 570.5 & -0.83 & 345.9 & -1.58 & 102.9 & 0.33 & 314.5 & 0.44 & 89.5 & 7.09 & 1054.4 & -4.84 & 106.6 & -0.12 & 2912.5 & -1.86 & 23185.5 & -0.69 \\
\hline 2019 & 230.6 & -1.58 & 92.0 & -1.86 & 553.0 & -3.06 & 345.4 & -0.14 & 100.9 & -1.97 & 309.1 & -1.70 & 89.9 & 0.42 & 1072.9 & 1.76 & 107.6 & 0.88 & 2901.6 & -0.38 & 23094.9 & -0.39 \\
\hline Ort & & -0.71 & & -3.29 & & -1.07 & & 1.42 & & 0.12 & & -1.63 & & -0.47 & & -1.58 & & 1.27 & & -1.18 & & -0.62 \\
\hline
\end{tabular}


Çizelge 5. Güneydoğu Anadolu Bölgesi illerinin 2010-2019 yıllarındaki toplam traktör sayıları Table 5. Total number of tractors of the Southeastern Anatolia Region provinces between 2010-2019

\begin{tabular}{|c|c|c|c|c|c|c|c|c|c|c|c|c|c|c|c|c|c|c|c|c|c|c|}
\hline & है & $\frac{\overline{0}}{0}$ & & $\frac{c}{\sigma}$ & & & 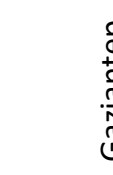 & 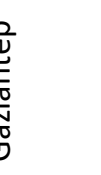 & & & & $\frac{5}{\frac{c}{0}}$ & 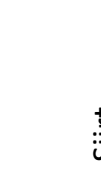 & $\underline{n}$ & 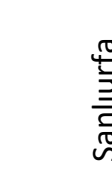 & & & $\frac{\sqrt{0}}{\frac{\pi}{n}}$ & 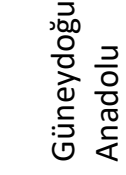 & $\begin{array}{l}\overline{\tilde{n}} \\
\stackrel{\infty}{0} \\
\vdots \bar{\infty}\end{array}$ & 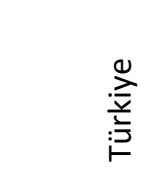 & \\
\hline$\stackrel{\frac{\grave{\pi}}{\bar{亠}}}{\overline{\bar{\nu}}}$ & 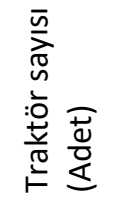 & 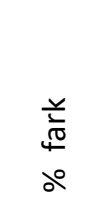 & 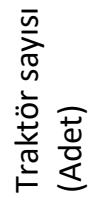 & 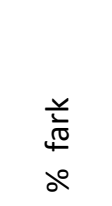 & 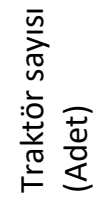 & 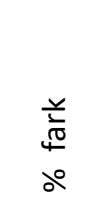 & 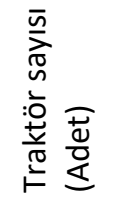 & $\begin{array}{l}\frac{v}{\grave{E}} \\
\text { do }\end{array}$ & 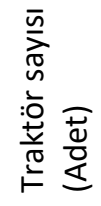 & 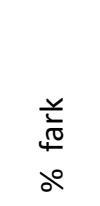 & 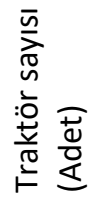 & 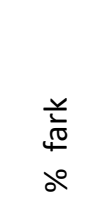 & 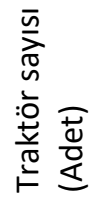 & $\begin{array}{l}\frac{2}{i} \\
\stackrel{ }{ \pm} \\
\text { do }\end{array}$ & 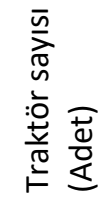 & $\begin{array}{l}\frac{2}{i} \\
\stackrel{ }{ \pm} \\
\text { do }\end{array}$ & 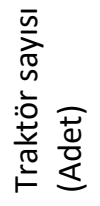 & 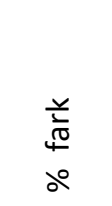 & 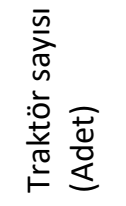 & 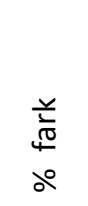 & 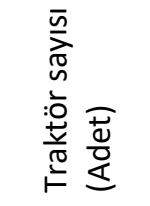 & 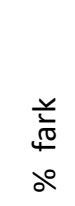 \\
\hline 2010 & 10702 & & 1726 & & 9125 & & 10093 & & 1554 & & 4971 & & 1819 & & 14024 & & 2054 & & 56068 & & 1096421 & \\
\hline 2011 & 10578 & -1.16 & 1872 & 8.46 & 9121 & -0.04 & 10173 & 0.79 & 1565 & 0.71 & 5043 & 1.45 & 2054 & 12.92 & 14910 & 6.32 & 1651 & -19.62 & 56967 & 1.58 & 1124596 & 2.51 \\
\hline 2012 & 11197 & 5.85 & 1744 & -6.84 & 9234 & 1.24 & 14335 & 40.91 & 1790 & 14.38 & 5016 & -0.54 & 2205 & 7.35 & 15693 & 5.25 & 1873 & 13.45 & 63087 & 9.70 & 1177815 & 4.52 \\
\hline 2013 & 11428 & 2.06 & 1763 & 1.09 & 9363 & 1.40 & 14416 & 0.57 & 1811 & 1.17 & 5307 & 5.80 & 2099 & -4.81 & 15740 & 0.30 & 1883 & 0.53 & 63810 & 1.13 & 1213136 & 2.91 \\
\hline 2014 & 12065 & 5.57 & 1497 & -15.09 & 9449 & 0.92 & 14775 & 2.49 & 1854 & 2.37 & 5094 & -4.01 & 2350 & 11.96 & 16203 & 2.94 & 1899 & 0.85 & 65186 & 2.11 & 1242910 & 2.40 \\
\hline 2015 & 12560 & 4.10 & 1550 & 3.54 & 9266 & -1.94 & 14801 & 0.18 & 1884 & 1.62 & 5284 & 3.73 & 2384 & 1.45 & 16549 & 2.14 & 1911 & 0.63 & 66189 & 1.52 & 1259968 & 1.35 \\
\hline 2016 & 12625 & 0.52 & 1510 & -2.58 & 9315 & 0.53 & 14891 & 0.61 & 1924 & 2.12 & 5336 & 0.98 & 2442 & 2.43 & 16729 & 1.09 & 1918 & 0.37 & 66690 & 0.75 & 1273217 & 1.04 \\
\hline 2017 & 12735 & 0.87 & 1518 & 0.53 & 9547 & 2.49 & 14989 & 0.66 & 1989 & 3.38 & 5873 & 10.06 & 2554 & 4.59 & 17206 & 2.85 & 1923 & 0.26 & 68334 & 2.41 & 1306427 & 2.54 \\
\hline 2018 & 12863 & 1.01 & 1577 & 3.89 & 9586 & 0.41 & 15145 & 1.04 & 2002 & 0.65 & 6199 & 5.55 & 2713 & 6.23 & 17385 & 1.04 & 1870 & -2.76 & 69340 & 1.45 & 1331830 & 1.91 \\
\hline 2019 & 14287 & 11.07 & 1592 & 0.95 & 9801 & 2.24 & 15222 & 0.51 & 2063 & 3.05 & 6286 & 1.40 & 2737 & 0.88 & 17760 & 2.16 & 1728 & -7.59 & 71476 & 2.99 & 1354803 & 1.70 \\
\hline Ort & & 3.32 & & -0.67 & & 0.80 & & 5.31 & & 3.27 & & 2.71 & & 4.78 & & 2.68 & & -1.54 & & 2.63 & & 2.32 \\
\hline
\end{tabular}


Çizelge 6. Güneydoğu Anadolu Bölgesi illerinin 2010-2019 yıllarındaki ortalama traktör gücü (kW) değerleri Table 6. Average tractor power (kW) values of the Southeastern Anatolia Region provinces between 2010-2019

\begin{tabular}{|c|c|c|c|c|c|c|c|c|c|c|c|c|c|c|c|c|c|c|c|c|c|c|}
\hline & . & $\frac{5}{\frac{1}{0}}$ & & 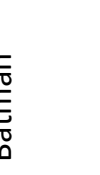 & - & & 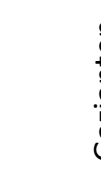 & & 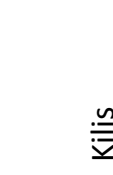 & & & & & $\frac{5}{\bar{n}}$ & 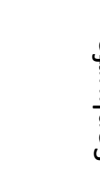 & & & & 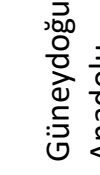 & 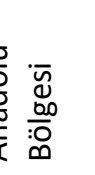 & & \\
\hline$\frac{\frac{\bar{\sigma}}{\bar{亠}}}{\overline{\bar{\nu}}}$ & 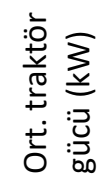 & 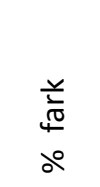 & 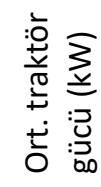 & 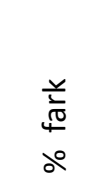 & 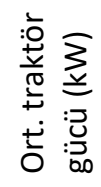 & $\begin{array}{l}\frac{2}{\frac{1}{\pi}} \\
\stackrel{0}{\circ}\end{array}$ & 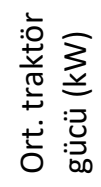 & 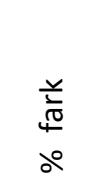 & 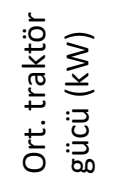 & 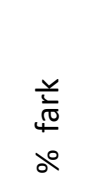 & 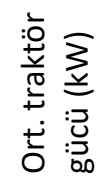 & 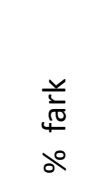 & 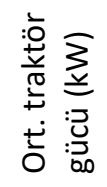 & 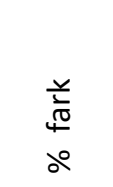 & 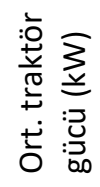 & $\begin{array}{l}\frac{2}{\frac{1}{\pi}} \\
\text { do }\end{array}$ & 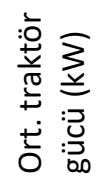 & $\begin{array}{l}\frac{2}{\frac{1}{\pi}} \\
\text { do }\end{array}$ & 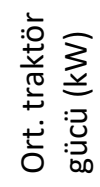 & 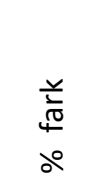 & 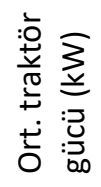 & 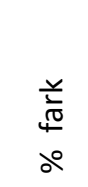 \\
\hline 2010 & 41.65 & & 42.31 & & 40.37 & & 35.62 & & 33.23 & & 35.51 & & 34.83 & & 44.11 & & 39.37 & & 39.91 & & 37.06 & \\
\hline 2011 & 41.40 & -0.59 & 42.51 & 0.48 & 40.33 & -0.08 & 35.61 & -0.03 & 33.24 & 0.02 & 35.61 & 0.29 & 32.32 & -7.19 & 44.24 & 0.29 & 39.42 & 0.13 & 39.85 & -0.15 & 36.87 & -0.52 \\
\hline 2012 & 41.07 & -0.80 & 42.23 & -0.66 & 40.21 & -0.31 & 35.11 & -1.39 & 34.39 & 3.47 & 35.63 & 0.03 & 28.73 & -11.14 & 44.87 & 1.43 & 41.91 & 6.30 & 39.54 & -0.78 & 36.98 & 0.30 \\
\hline 2013 & 41.11 & 0.09 & 42.22 & -0.02 & 40.20 & -0.01 & 35.10 & -0.03 & 34.60 & 0.60 & 36.73 & 3.10 & 29.04 & 1.10 & 44.76 & -0.25 & 41.84 & -0.15 & 39.63 & 0.23 & 37.09 & 0.30 \\
\hline 2014 & 40.91 & -0.48 & 42.18 & -0.10 & 40.22 & 0.03 & 34.88 & -0.64 & 34.96 & 1.03 & 43.18 & 17.55 & 28.46 & -2.01 & 44.83 & 0.16 & 42.18 & 0.81 & 40.04 & 1.02 & 36.98 & -0.30 \\
\hline 2015 & 40.93 & 0.05 & 42.31 & 0.31 & 40.83 & 1.52 & 34.88 & 0.01 & 34.96 & 0.02 & 43.65 & 1.10 & 28.91 & 1.60 & 44.89 & 0.14 & 42.17 & -0.03 & 40.24 & 0.50 & 37.14 & 0.43 \\
\hline 2016 & 40.96 & 0.07 & 41.04 & -3.00 & 40.85 & 0.05 & 34.89 & 0.02 & 35.16 & 0.56 & 43.56 & -0.21 & 29.65 & 2.56 & 44.96 & 0.14 & 42.11 & -0.15 & 40.25 & 0.02 & 37.23 & 0.24 \\
\hline 2017 & 41.06 & 0.25 & 41.50 & 1.13 & 41.03 & 0.46 & 34.91 & 0.06 & 35.62 & 1.32 & 43.83 & 0.62 & 29.96 & 1.03 & 44.98 & 0.06 & 42.20 & 0.21 & 40.40 & 0.37 & 37.49 & 0.69 \\
\hline 2018 & 41.16 & 0.24 & 41.24 & -0.63 & 41.04 & 0.01 & 34.93 & 0.08 & 35.71 & 0.24 & 44.00 & 0.39 & 28.85 & -3.69 & 44.99 & 0.01 & 42.13 & -0.17 & 40.39 & -0.02 & 37.68 & 0.50 \\
\hline 2019 & 39.81 & -3.28 & 41.08 & -0.39 & 41.71 & 1.65 & 34.91 & -0.07 & 35.79 & 0.24 & 44.23 & 0.51 & 28.85 & -0.01 & 45.07 & 0.19 & 46.38 & 10.09 & 40.38 & -0.02 & 37.88 & 0.53 \\
\hline Ort & & -0.49 & & -0.32 & & 0.37 & & -0.22 & & 0.83 & & 2.60 & & -1.97 & & 0.24 & & 1.89 & & 0.13 & & 0.24 \\
\hline
\end{tabular}


Çizelge 7. Güneydoğu Anadolu Bölgesi illerinin 2010-2019 yıllarındaki toplam traktör gücü (kW) değerleri Table 7. Total tractor power (kW) values of the Southeastern Anatolia Region provinces between 2010-2019

\begin{tabular}{|c|c|c|c|c|c|c|c|c|c|c|c|c|c|c|c|c|c|c|c|c|c|c|}
\hline & z & $\frac{\overline{0}}{\frac{0}{5}}$ & & 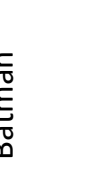 & 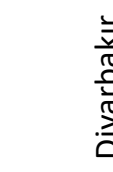 & & $\begin{array}{l}0 \\
\stackrel{0}{ \pm} \\
\stackrel{0}{N} \\
\stackrel{0}{N} \\
\mathbb{0} \\
0\end{array}$ & & 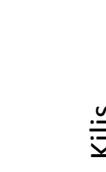 & & & & 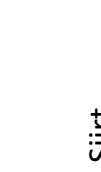 & $\underline{E}$ & $\frac{\mathscr{T}}{\Xi}$ & & & $\bar{n}$ & 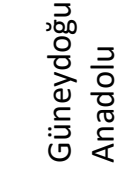 & & 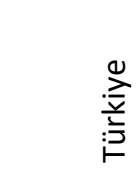 & \\
\hline$\frac{\frac{1}{\overline{0}}}{\overline{\bar{亠}}}$ & 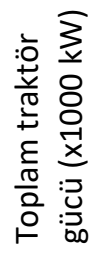 & 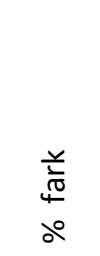 & 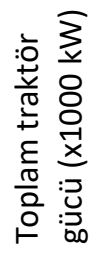 & 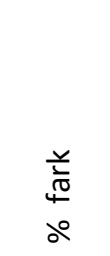 & 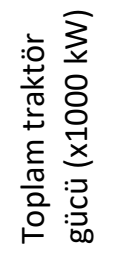 & 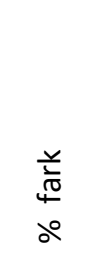 & 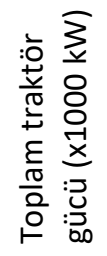 & 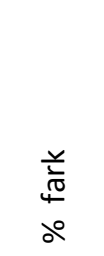 & 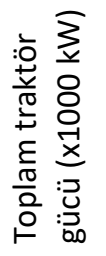 & 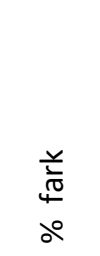 & 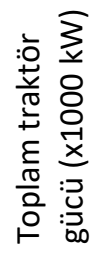 & $\begin{array}{l}\frac{2}{\frac{1}{\pi}} \\
\text { do } \\
\text { dᄋ }\end{array}$ & 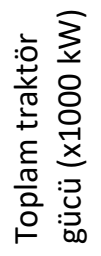 & $\begin{array}{l}\frac{2}{\frac{1}{\pi}} \\
\text { d0 } \\
\text { dᄋ }\end{array}$ & 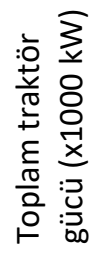 & 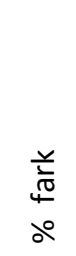 & 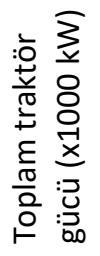 & $\begin{array}{l}\frac{2}{\frac{1}{\pi}} \\
\text { d0 } \\
\text { dᄋ }\end{array}$ & 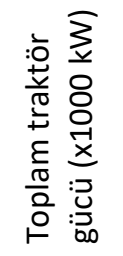 & $\begin{array}{l}\frac{y}{\frac{1}{\pi}} \\
\text { வ0 }\end{array}$ & 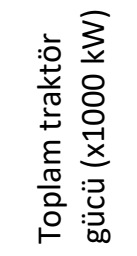 & 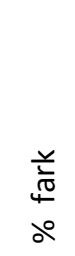 \\
\hline 2010 & 445.7 & & 73.0 & & 368.4 & & 359.5 & & 51.6 & & 176.5 & & 63.4 & & 618.6 & & 80.9 & & 2237.6 & & 40632.9 & \\
\hline 2011 & 437.9 & -1.74 & 79.6 & 8.98 & 367.9 & -0.13 & 362.2 & 0.76 & 52.0 & 0.73 & 179.6 & 1.74 & 66.4 & 4.80 & 659.6 & 6.63 & 65.1 & -19.52 & 2270.3 & 1.44 & 41459.1 & 1.99 \\
\hline 2012 & 459.9 & 5.01 & 73.6 & -7.45 & 371.3 & 0.92 & 503.3 & 38.95 & 61.6 & 18.35 & 178.7 & -0.50 & 63.3 & -4.60 & 704.2 & 6.76 & 78.5 & 20.59 & 2494.4 & 8.98 & 43560.5 & 4.82 \\
\hline 2013 & 469.8 & 2.16 & 74.4 & 1.07 & 376.4 & 1.39 & 506.0 & 0.53 & 62.7 & 1.78 & 194.9 & 9.08 & 61.0 & -3.76 & 704.5 & 0.04 & 78.8 & 0.38 & 2528.5 & 1.35 & 45000.0 & 3.20 \\
\hline 2014 & 493.6 & 5.07 & 63.1 & -15.18 & 380.0 & 0.95 & 515.3 & 1.84 & 64.8 & 3.43 & 219.9 & 12.84 & 66.9 & 9.71 & 726.4 & 3.10 & 80.1 & 1.67 & 2610.2 & 3.13 & 45961.9 & 2.09 \\
\hline 2015 & 514.1 & 4.16 & 65.6 & 3.86 & 378.3 & -0.45 & 516.2 & 0.18 & 65.9 & 1.63 & 230.7 & 4.87 & 68.9 & 3.07 & 742.9 & 2.28 & 80.6 & 0.60 & 2663.2 & 1.99 & 46800.7 & 1.79 \\
\hline 2016 & 517.2 & 0.59 & 62.0 & -5.50 & 380.5 & 0.58 & 519.5 & 0.63 & 67.6 & 2.70 & 232.4 & 0.77 & 72.4 & 5.05 & 752.1 & 1.23 & 80.8 & 0.22 & 2684.4 & 0.79 & 47399.0 & 1.26 \\
\hline 2017 & 523.0 & 1.12 & 63.0 & 1.67 & 391.7 & 2.96 & 523.2 & 0.72 & 70.9 & 4.74 & 257.4 & 10.75 & 76.5 & 5.66 & 774.0 & 2.91 & 81.1 & 0.48 & 2760.9 & 2.77 & 48982.8 & 3.23 \\
\hline 2018 & 529.5 & 1.25 & 65.0 & 3.23 & 393.4 & 0.42 & 529.1 & 1.12 & 71.5 & 0.89 & 272.8 & 5.97 & 78.3 & 2.30 & 782.2 & 1.06 & 78.8 & -2.92 & 2800.5 & 1.41 & 50180.8 & 2.39 \\
\hline 2019 & 568.8 & 7.43 & 65.4 & 0.56 & 408.8 & 3.93 & 531.4 & 0.44 & 73.8 & 3.29 & 278.0 & 1.92 & 79.0 & 0.88 & 800.5 & 2.35 & 80.1 & 1.73 & 2885.9 & 2.96 & 51326.6 & 2.23 \\
\hline Ort & & 2.8 & & -1.0 & & 1.2 & & 5.0 & & 4.2 & & 5.3 & & 2.6 & & 2.9 & & 0.4 & & 2.76 & & 2.56 \\
\hline
\end{tabular}


Çizelge 8. Güneydoğu Anadolu Bölgesi illerinin 2010-2019 yıllarındaki toplam tarım alet-makina sayıları Table 8. Total number of agricultural equipment-machine of the Southeastern Anatolia Region provinces between 2010-2019

\begin{tabular}{|c|c|c|c|c|c|c|c|c|c|c|c|c|c|c|c|c|c|c|c|c|c|c|}
\hline \multirow[b]{2}{*}{$\frac{\bar{\Xi}}{\overline{\bar{\nu}}}$} & \multicolumn{2}{|c|}{$\begin{array}{l}\frac{1}{\sqrt{0}} \\
\frac{8}{0} \\
\frac{0}{2} \\
\frac{0}{4}\end{array}$} & \multicolumn{2}{|c|}{ 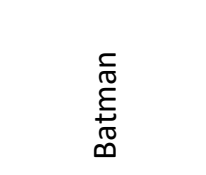 } & \multicolumn{2}{|c|}{$\begin{array}{l}\frac{1}{\frac{1}{\pi}} \\
\frac{0}{\frac{2}{\pi}} \\
\frac{0}{\frac{1}{0}} \\
\frac{0}{0}\end{array}$} & \multicolumn{2}{|c|}{ 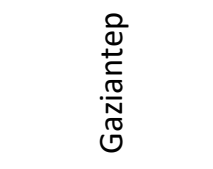 } & \multicolumn{2}{|c|}{$\stackrel{\cong}{\overline{\bar{x}}}$} & \multicolumn{2}{|c|}{$\frac{\frac{5}{0}}{\frac{5}{\pi}}$} & \multicolumn{2}{|c|}{ : } & \multicolumn{2}{|c|}{ 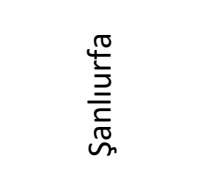 } & \multicolumn{2}{|c|}{ 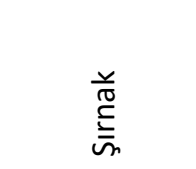 } & \multicolumn{2}{|c|}{ 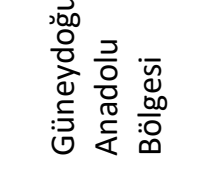 } & \multicolumn{2}{|l|}{ 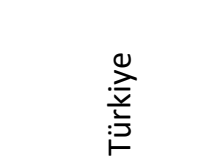 } \\
\hline & 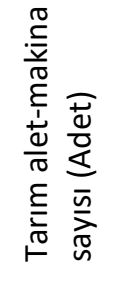 & 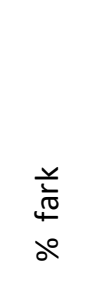 & 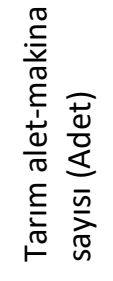 & 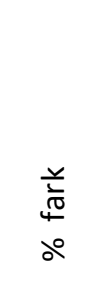 & 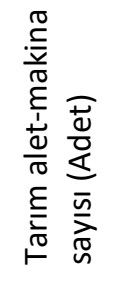 & 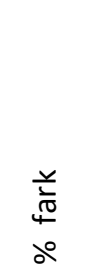 & 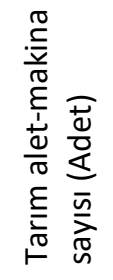 & $\begin{array}{l}\frac{2}{\frac{1}{\sigma}} \\
\text { வ0 }\end{array}$ & 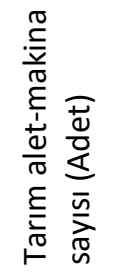 & 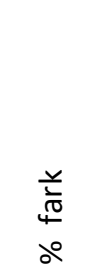 & 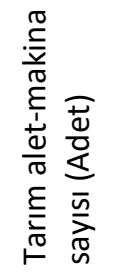 & 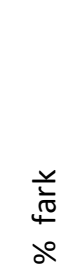 & 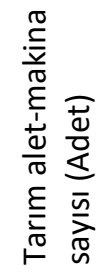 & 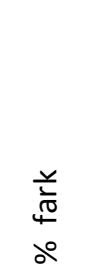 & 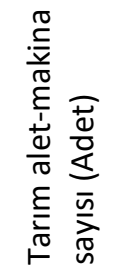 & 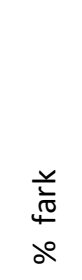 & 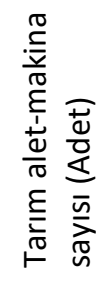 & $\begin{array}{l}\frac{2}{\frac{1}{\pi}} \\
\text { வ0 }\end{array}$ & 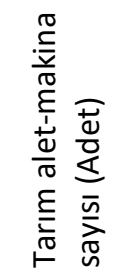 & 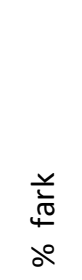 & 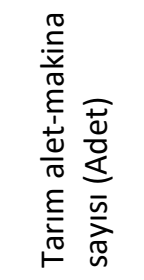 & $\begin{array}{l}\frac{2}{\frac{L}{\sigma}} \\
\text { வீ }\end{array}$ \\
\hline 2010 & 44402 & & 10148 & & 58082 & & 39322 & & 9385 & & 23979 & & 7062 & & 83319 & & 7039 & & 282738 & & 5684915 & \\
\hline 2011 & 45502 & 2.48 & 10840 & 6.82 & 62222 & 7.13 & 39956 & 1.61 & 9322 & -0.67 & 24181 & 0.84 & 7610 & 7.76 & 89448 & 7.36 & 5387 & -23.47 & 294468 & 3.98 & 5777676 & 1.61 \\
\hline 2012 & 46052 & 1.21 & 11233 & 3.63 & 62927 & 1.13 & 53931 & 34.98 & 10533 & 12.99 & 24945 & 3.16 & 7812 & 2.65 & 92158 & 3.03 & 5810 & 7.85 & 315401 & 6.64 & 5904004 & 2.14 \\
\hline 2013 & 48922 & 6.23 & 11400 & 1.49 & 63629 & 1.12 & 54778 & 1.57 & 10665 & 1.25 & 25343 & 1.60 & 8101 & 3.70 & 92418 & 0.28 & 5756 & -0.93 & 321012 & 1.75 & 5961410 & 0.96 \\
\hline 2014 & 50139 & 2.49 & 11054 & -3.04 & 65698 & 3.25 & 56141 & 2.49 & 10970 & 2.86 & 27327 & 7.83 & 8634 & 6.58 & 96084 & 3.97 & 5780 & 0.42 & 331827 & 3.26 & 6021584 & 1.00 \\
\hline 2015 & 50993 & 1.70 & 11643 & 5.33 & 65773 & 0.11 & 56428 & 0.51 & 11397 & 3.89 & 28472 & 4.19 & 8736 & 1.18 & 98133 & 2.13 & 5885 & 1.82 & 337460 & 1.67 & 6092563 & 1.17 \\
\hline 2016 & 51469 & 0.93 & 11824 & 1.55 & 66056 & 0.43 & 57035 & 1.08 & 12059 & 5.81 & 29317 & 2.97 & 8850 & 1.30 & 100260 & 2.17 & 5936 & 0.87 & 342806 & 1.56 & 6170512 & 1.26 \\
\hline 2017 & 52266 & 1.55 & 12201 & 3.19 & 68506 & 3.71 & 57650 & 1.08 & 12333 & 2.27 & 30378 & 3.62 & 9467 & 6.97 & 102029 & 1.76 & 6024 & 1.48 & 350854 & 2.29 & 6292882 & 1.94 \\
\hline 2018 & 53498 & 2.36 & 12249 & 0.39 & 66591 & -2.80 & 57975 & 0.56 & 12621 & 2.34 & 31525 & 3.78 & 9080 & -4.09 & 103121 & 1.07 & 6248 & 3.72 & 352908 & 0.58 & 6388075 & 1.49 \\
\hline 2019 & 55741 & 4.19 & 12413 & 1.34 & 67122 & 0.80 & 58439 & 0.80 & 13296 & 5.35 & 32410 & 2.81 & 9153 & 0.80 & 103775 & 0.63 & 7729 & 23.70 & 360078 & 1.99 & 6476083 & 1.36 \\
\hline Ort & & 2.57 & & 2.30 & & 1.65 & & 4.96 & & 4.01 & & 3.42 & & 2.99 & & 2.49 & & 1.72 & & 2.64 & & 1.44 \\
\hline
\end{tabular}


Güneydoğu Anadolu Bölgesi geneli ve illerinin, 20102019 yıllarında traktör başına düşen alet-makina sayısı; Adıyaman, Gaziantep, Siirt, Şanlıurfa'da azalmış, Batman, Diyarbakır, Kilis, Mardin ve Şırnak'ta artmış, Bölge genelinde ise azalmıştır (Şekil 4). On yıllık süreçte, makina traktör ${ }^{-1}$ oranındaki azalma; makina sayılarındaki artış oranlarının (Çizelge 8) traktör sayılarındaki artış oranlarından (Çizelge 5) daha az olmasından, makina traktör ${ }^{-1}$ oranındaki artış ise makina sayılarındaki artış oranlarının traktör sayılarındaki artış oranlarından daha fazla olmasından kaynaklanmaktadır.

Güneydoğu Anadolu Bölgesi ve illerinin gelecek yıllar (2020-2030) için mekanizasyon düzeyi gösterge değerlerinden, işlenen alana düşen traktör gücü ( $\mathrm{kW}$ ha' $\left.{ }^{1}\right)$ değerlerinin belirlenmesi için 2010-2019 yıllarındaki kW ha ${ }^{-1}$ değerlerinin değişiminden, trend analizi yapılmıştır. Bu analize göre $\mathrm{kW}$ ha-1 değeri; bölge geneli ve tüm illerde gelecek yıllara göre artış göstereceği görülmüştür (Şekil 5). Bölge genelinde 2020-2030 yıllarının ortalama artış değerinin \%2.47 olması tahmin edilmiş ve bu değer Türkiye ortalamasının (\%2.22) üzerinde oluşmuştur. $\mathrm{kW}$ ha ${ }^{-1}$ değeri; bölge geneli için 2020 yılında 1.02, 2025 yılında 1.16 ve 2030 yılında 1.31 olması tahmin edilmektedir (Çizelge 13).

Gelişmiş ülkelerin yer aldığı $A B^{\prime}$ de 2010 yılı verilerine göre mekanizasyon gösterge değerleri $6 \mathrm{~kW} \mathrm{ha}^{-1}, 11.30$ ha traktör ${ }^{-1}, 89$ traktör 1000 ha $^{-1}, 10$ makina traktör $^{-1}$ olmaktadır (ileri, 2010; Gökdoğan 2012). Güneydoğu Anadolu Bölgesinde mekanizasyon düzeyi yıllara göre iyileşme sağlamakta, ancak bu düzeyin iyileşme hızı $A B^{\prime}$ ye göre çok düşük olmaktadır. 
Çizelge 9. Güneydoğu Anadolu Bölgesi illerinin 2010-2019 yıllarında işlenen alana düşen traktör gücü ( $k W$ ha $^{-1}$ )

Table 9. Tractor power per unit cultivated area $\left(\mathrm{kW} \mathrm{ha}^{-1}\right)$ of the Southeastern Anatolia Region provinces between 2010-2019

\begin{tabular}{|c|c|c|c|c|c|c|c|c|c|c|}
\hline $\begin{array}{l}\frac{1}{\sqrt{0}} \\
\sum_{\frac{1}{0}}^{\frac{1}{2}} \\
\frac{1}{2}\end{array}$ & 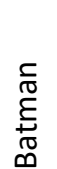 & $\begin{array}{l}\frac{1}{\frac{1}{0}} \\
\frac{0}{2} \\
\frac{2}{10} \\
\frac{\overline{1}}{0}\end{array}$ & 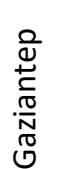 & $\stackrel{\varrho}{\underline{\overline{\bar{x}}}}$ & $\frac{.5}{\frac{5}{0}}$ & $:$ & 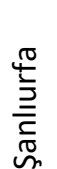 & $\begin{array}{l}\frac{v}{\mathbb{N}} \\
\stackrel{5}{\bar{N}}\end{array}$ & 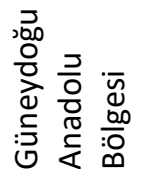 & $\frac{0}{\stackrel{\bar{z}}{\bar{z}}}$ \\
\hline
\end{tabular}

\begin{tabular}{|c|c|c|c|c|c|c|c|c|c|c|c|c|c|c|c|c|c|c|c|c|c|c|}
\hline$\frac{\grave{i}}{\bar{\equiv}}$ & $\frac{\sqrt{1}}{\underline{0}}$ & 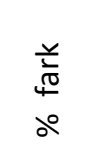 & $\frac{-1}{1}$ & 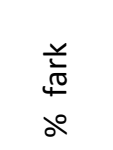 & 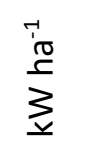 & 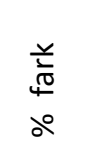 & $\frac{-1}{1}$ & 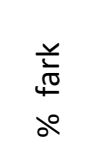 & 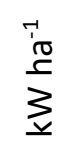 & 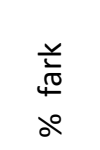 & 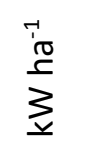 & 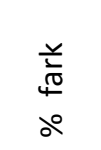 & 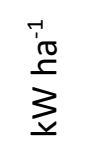 & 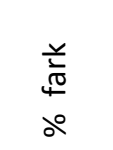 & $\frac{i}{\mathscr{C}}$ & 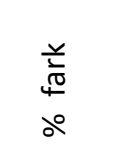 & 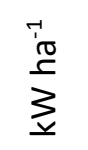 & 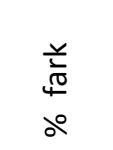 & 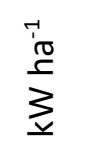 & 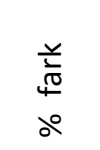 & 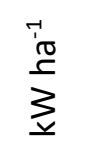 & 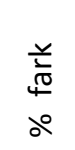 \\
\hline 2010 & 1.81 & & 0.58 & & 0.60 & & 1.16 & & 0.52 & & 0.49 & & 0.66 & & 0.49 & & 0.78 & & 0.70 & & 1.67 & \\
\hline 2011 & 1.83 & 0.88 & 0.62 & 6.07 & 0.61 & 1.90 & 1.17 & 0.51 & 0.52 & 1.14 & 0.56 & 13.86 & 0.79 & 21.03 & 0.58 & 17.32 & 0.65 & -17.01 & 0.75 & 6.67 & 1.76 & 5.11 \\
\hline 2012 & 1.96 & 7.59 & 0.59 & -3.94 & 0.65 & 5.92 & 1.37 & 17.22 & 0.60 & 14.20 & 0.55 & -0.54 & 0.69 & -12.78 & 0.66 & 13.98 & 0.82 & 27.36 & 0.84 & 10.71 & 1.83 & 3.83 \\
\hline 2013 & 1.95 & -0.66 & 0.63 & 6.66 & 0.63 & -3.78 & 1.40 & 2.00 & 0.60 & -0.32 & 0.60 & 9.12 & 0.75 & 7.76 & 0.58 & -12.10 & 0.78 & -5.56 & 0.80 & -5.00 & 1.89 & 3.17 \\
\hline 2014 & 2.05 & 5.29 & 0.55 & -13.26 & 0.62 & -1.22 & 1.43 & 1.87 & 0.61 & 3.36 & 0.66 & 9.66 & 0.85 & 14.34 & 0.61 & 6.46 & 0.80 & 2.78 & 0.83 & 3.61 & 1.92 & 1.56 \\
\hline 2015 & 2.14 & 4.37 & 0.59 & 6.74 & 0.62 & 0.98 & 1.44 & 0.95 & 0.63 & 1.97 & 0.70 & 6.00 & 0.81 & -4.88 & 0.63 & 2.29 & 0.85 & 6.73 & 0.86 & 3.49 & 1.96 & 2.04 \\
\hline 2016 & 2.15 & 0.17 & 0.61 & 4.23 & 0.65 & 3.34 & 1.47 & 2.05 & 0.65 & 3.13 & 0.74 & 5.41 & 0.82 & 0.55 & 0.65 & 3.53 & 1.04 & 21.55 & 0.89 & 3.37 & 2.00 & 2.00 \\
\hline 2017 & 2.23 & 3.73 & 0.69 & 13.36 & 0.68 & 5.57 & 1.49 & 1.41 & 0.69 & 6.77 & 0.82 & 10.98 & 0.92 & 12.17 & 0.70 & 7.30 & 0.76 & -26.70 & 0.93 & 4.30 & 2.10 & 4.76 \\
\hline 2018 & 2.26 & 1.43 & 0.69 & 0.30 & 0.69 & 1.26 & 1.53 & 2.74 & 0.69 & 0.57 & 0.87 & 5.50 & 0.87 & -4.47 & 0.74 & 6.19 & 0.74 & -2.81 & 0.96 & 3.12 & 2.16 & 2.78 \\
\hline 2019 & 2.47 & 9.15 & 0.71 & 2.46 & 0.74 & 7.21 & 1.54 & 0.58 & 0.73 & 5.36 & 0.90 & 3.68 & 0.88 & 0.45 & 0.75 & 0.58 & 0.74 & 0.84 & 0.99 & 3.03 & 2.22 & 2.70 \\
\hline Ort & & 3.55 & & 2.51 & & 2.35 & & 3.26 & & 4.02 & & 7.08 & & 3.80 & & 5.06 & & 0.80 & & 3.70 & & 3.11 \\
\hline
\end{tabular}


Çizelge 10. Güneydoğu Anadolu Bölgesi illerinin 2010-2019 yıllarında 1000 ha alana düşen traktör sayısı (traktör $1000 \mathrm{ha}^{-1}$ )

Table 10. Number of tractors per 1000 ha areas (tractor $1000 \mathrm{ha}^{-1}$ ) of the Southeastern Anatolia Region provinces between 2010-2019

\begin{tabular}{|c|c|c|c|c|c|c|c|c|c|c|c|c|c|c|c|c|c|c|c|c|c|c|}
\hline & & $\underline{\underline{\sigma}}$ & & 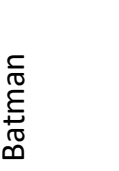 & & & 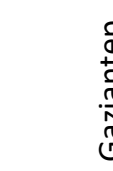 & $\begin{array}{l}\frac{2}{y} \\
\frac{1}{2} \\
\frac{1}{2} \\
0 \\
0\end{array}$ & 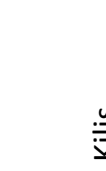 & & & $\frac{5}{\frac{5}{0}}$ & & & & & & $\frac{\frac{\pi}{\sigma}}{\frac{n}{n}}$ & 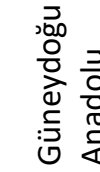 & $\begin{array}{l}\overline{\tilde{y}} \\
\stackrel{0}{0} \\
\vdots \overline{0}\end{array}$ & 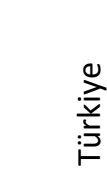 & \\
\hline$\frac{\frac{1}{\pi}}{\overline{\bar{亠}}}$ & 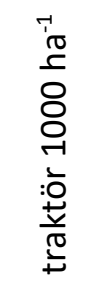 & 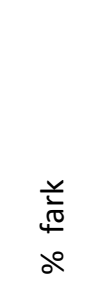 & 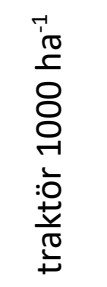 & 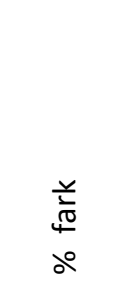 & 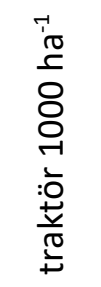 & 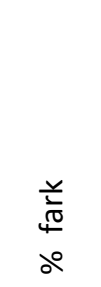 & 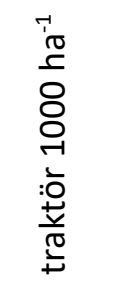 & 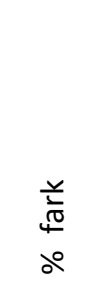 & 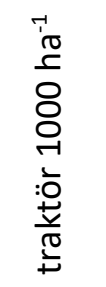 & 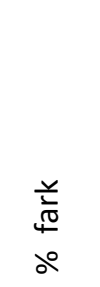 & 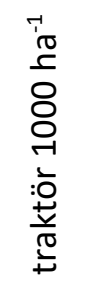 & 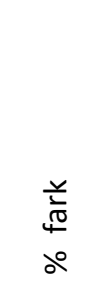 & 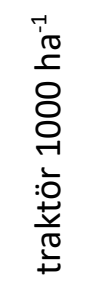 & 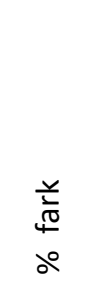 & 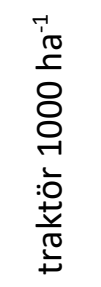 & 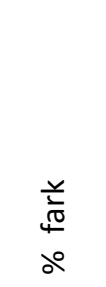 & 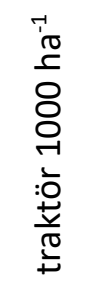 & 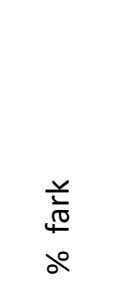 & 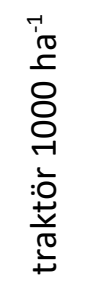 & 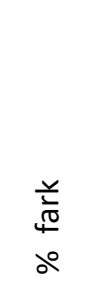 & 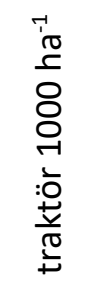 & 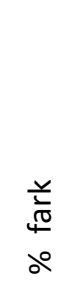 \\
\hline 2010 & 43.44 & & 13.75 & & 14.93 & & 32.68 & & 15.55 & & 13.78 & & 18.83 & & 11.14 & & 19.79 & & 17.45 & & 44.95 & \\
\hline 2011 & 44.09 & 1.48 & 14.51 & 5.57 & 15.22 & 1.99 & 32.86 & 0.54 & 15.72 & 1.12 & 15.64 & 13.53 & 24.56 & 30.40 & 13.03 & 16.97 & 16.40 & -17.11 & 18.81 & 7.23 & 47.62 & 5.61 \\
\hline 2012 & 47.82 & 8.46 & 14.03 & -3.31 & 16.18 & 6.25 & 39.06 & 18.88 & 17.35 & 10.37 & 15.55 & -0.57 & 24.10 & -1.85 & 14.64 & 12.37 & 19.65 & 19.81 & 21.17 & 11.15 & 49.53 & 3.86 \\
\hline 2013 & 47.45 & -0.76 & 14.97 & 6.67 & 15.57 & -3.77 & 39.85 & 2.03 & 17.20 & -0.91 & 16.46 & 5.84 & 25.69 & 6.58 & 12.90 & -11.87 & 18.59 & -5.42 & 20.24 & -4.59 & 50.96 & 2.81 \\
\hline 2014 & 50.20 & 5.79 & 13.00 & -13.17 & 15.37 & -1.25 & 40.86 & 2.53 & 17.59 & 2.31 & 15.35 & -6.72 & 29.98 & 16.69 & 13.71 & 6.29 & 18.95 & 1.95 & 20.83 & 2.83 & 51.92 & 1.85 \\
\hline 2015 & 52.37 & 4.31 & 13.83 & 6.41 & 15.29 & -0.54 & 41.25 & 0.94 & 17.94 & 1.95 & 16.10 & 4.85 & 28.07 & -6.38 & 14.01 & 2.14 & 20.23 & 6.76 & 21.28 & 2.11 & 52.64 & 1.37 \\
\hline 2016 & 52.42 & 0.10 & 14.86 & 7.45 & 15.79 & 3.29 & 42.08 & 2.03 & 18.39 & 2.56 & 17.01 & 5.63 & 27.52 & -1.96 & 14.48 & 3.39 & 24.63 & 21.73 & 22.04 & 3.45 & 53.70 & 1.97 \\
\hline 2017 & 54.24 & 3.48 & 16.66 & 12.09 & 16.60 & 5.09 & 42.65 & 1.34 & 19.38 & 5.38 & 18.76 & 10.30 & 30.55 & 11.02 & 15.53 & 7.24 & 18.01 & -26.86 & 23.03 & 4.30 & 55.96 & 4.04 \\
\hline 2018 & 54.89 & 1.19 & 16.82 & 0.93 & 16.80 & 1.25 & 43.78 & 2.66 & 19.45 & 0.33 & 19.71 & 5.09 & 30.30 & -0.81 & 16.49 & 6.18 & 17.54 & -2.64 & 23.81 & 3.28 & 57.44 & 2.58 \\
\hline 2019 & 61.94 & 12.85 & 17.30 & 2.86 & 17.72 & 5.47 & 44.07 & 0.65 & 20.44 & 5.11 & 20.33 & 3.16 & 30.44 & 0.46 & 16.55 & 0.39 & 16.06 & -8.40 & 24.63 & 3.33 & 58.66 & 2.08 \\
\hline Ort & & 4.10 & & 2.84 & & 1.98 & & 3.51 & & 3.13 & & 4.57 & & 6.02 & & 4.79 & & -1.13 & & 3.68 & & 2.91 \\
\hline
\end{tabular}


Çizelge 11. Güneydoğu Anadolu Bölgesi illerinin 2010-2019 yıllarında traktör başına düşen üretim alanı (ha traktör ${ }^{-1}$ ) Table 11. Production area per tractor (ha tractor ${ }^{-1}$ ) of the Southeastern Anatolia Region provinces between 2010-2019

\begin{tabular}{|c|c|c|c|c|c|c|c|c|c|c|c|c|c|c|c|c|c|c|c|c|c|c|}
\hline & & $\frac{c^{\frac{\pi}{0}}}{\frac{c}{0}}$ & & 豪 & 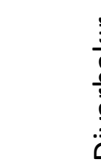 & & & 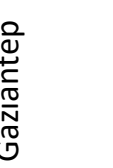 & 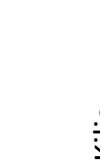 & & & $\frac{\frac{5}{0}}{\frac{0}{\frac{\pi}{\pi}}}$ & & : & & 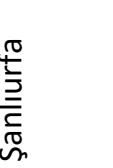 & & 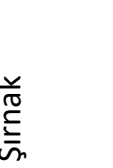 & 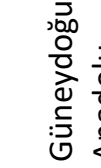 & 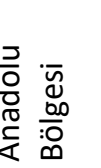 & 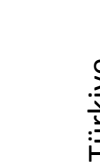 & 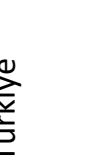 \\
\hline$\frac{\frac{1}{\bar{N}}}{\overline{\bar{\nu}}}$ & 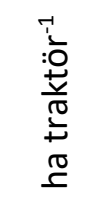 & 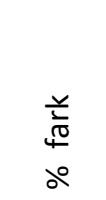 & 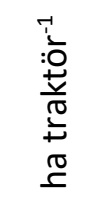 & 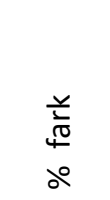 & 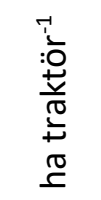 & $\begin{array}{l}\frac{y}{\frac{1}{\pi}} \\
\stackrel{0}{\circ}\end{array}$ & 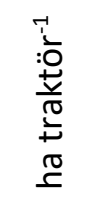 & $\begin{array}{l}\frac{2}{\frac{1}{\pi}} \\
\text { do }\end{array}$ & 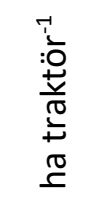 & $\begin{array}{l}\frac{y}{\frac{1}{\pi}} \\
\text { d0 }\end{array}$ & 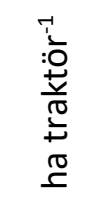 & 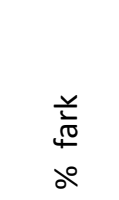 & 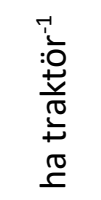 & $\begin{array}{l}\frac{2}{\frac{1}{\pi}} \\
\frac{0}{0}\end{array}$ & 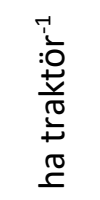 & $\begin{array}{l}\frac{2}{\frac{1}{\pi}} \\
\frac{0}{0}\end{array}$ & 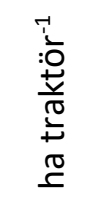 & 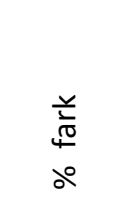 & 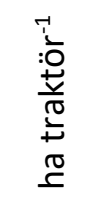 & 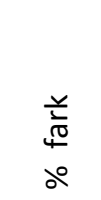 & 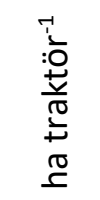 & 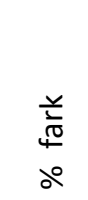 \\
\hline 2010 & 23.02 & & 72.73 & & 66.99 & & 30.60 & & 64.30 & & 72.58 & & 53.10 & & 89.79 & & 50.54 & & 57.29 & & 22.25 & \\
\hline 2011 & 22.68 & -1.46 & 68.90 & -5.28 & 65.68 & -1.95 & 30.44 & -0.54 & 63.60 & -1.10 & 63.94 & -11.92 & 40.72 & -23.31 & 76.76 & -14.51 & 60.97 & 20.65 & 53.16 & -7.77 & 21.00 & -5.95 \\
\hline 2012 & 20.91 & -7.80 & 71.25 & 3.42 & 61.82 & -5.89 & 25.60 & -15.88 & 57.62 & -9.39 & 64.30 & 0.57 & 41.49 & 1.88 & 68.31 & -11.01 & 50.89 & -16.54 & 47.25 & -12.51 & 20.19 & -4.01 \\
\hline 2013 & 21.07 & 0.76 & 66.79 & -6.26 & 64.24 & 3.92 & 25.09 & -1.99 & 58.15 & 0.92 & 60.75 & -5.52 & 38.92 & -6.18 & 77.51 & 13.47 & 53.80 & 5.73 & 49.41 & 4.37 & 19.62 & -2.91 \\
\hline 2014 & 19.92 & -5.48 & 76.92 & 15.16 & 65.05 & 1.26 & 24.47 & -2.47 & 56.84 & -2.25 & 65.13 & 7.20 & 33.36 & -14.30 & 72.92 & -5.92 & 52.77 & -1.91 & 48.00 & -2.94 & 19.26 & -1.87 \\
\hline 2015 & 19.10 & -4.13 & 72.29 & -6.02 & 65.41 & 0.54 & 24.25 & -0.93 & 55.76 & -1.91 & 62.11 & -4.63 & 35.63 & 6.82 & 71.39 & -2.10 & 49.43 & -6.33 & 47.00 & -2.13 & 19.00 & -1.37 \\
\hline 2016 & 19.08 & -0.10 & 67.28 & -6.93 & 63.32 & -3.19 & 23.76 & -1.99 & 54.37 & -2.49 & 58.80 & -5.33 & 36.34 & 2.00 & 69.06 & -3.28 & 40.61 & -17.85 & 45.38 & -3.57 & 18.62 & -2.04 \\
\hline 2017 & 18.43 & -3.36 & 60.02 & -10.79 & 60.25 & -4.84 & 23.45 & -1.33 & 51.59 & -5.11 & 53.31 & -9.34 & 32.73 & -9.93 & 64.39 & -6.75 & 55.52 & 36.72 & 43.41 & -4.54 & 17.87 & -4.20 \\
\hline 2018 & 18.22 & -1.18 & 59.46 & -0.93 & 59.51 & -1.23 & 22.84 & -2.59 & 51.42 & -0.33 & 50.73 & -4.84 & 33.00 & 0.81 & 60.65 & -5.82 & 57.02 & 2.71 & 42.00 & -3.36 & 17.41 & -2.64 \\
\hline 2019 & 16.14 & -11.39 & 57.81 & -2.78 & 56.42 & -5.19 & 22.69 & -0.65 & 48.92 & -4.87 & 49.18 & -3.06 & 32.85 & -0.46 & 60.41 & -0.39 & 62.25 & 9.17 & 40.60 & -3.45 & 17.05 & -2.11 \\
\hline Ort & & -3.79 & & -2.27 & & -1.84 & & -3.15 & & -2.95 & & -4.10 & & -4.74 & & -4.03 & & 3.59 & & -3.99 & & -3.01 \\
\hline
\end{tabular}


Çizelge 12. Güneydoğu Anadolu Bölgesi illerinin 2010-2019 yıllarında traktör başına düşen alet-makina sayısı (makina traktör ${ }^{-1}$ ) Table 12. Number of equipment-machine per tractor (machine tractor $^{-1}$ ) of the Southeastern Anatolia Region provinces between 2010-2019

\begin{tabular}{|c|c|c|c|c|c|c|c|c|c|c|c|c|c|c|c|c|c|c|c|c|c|c|}
\hline \multirow[b]{2}{*}{$\frac{\frac{\bar{\pi}}{\bar{亠}}}{\overline{\bar{\nu}}}$} & \multicolumn{2}{|c|}{ 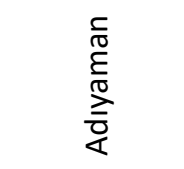 } & \multicolumn{2}{|c|}{ 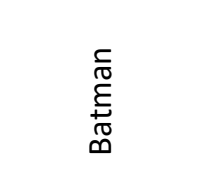 } & \multicolumn{2}{|c|}{$\begin{array}{l}\frac{1}{\frac{1}{0}} \\
\frac{0}{2} \\
\frac{0}{0} \\
\stackrel{0}{\frac{1}{2}}\end{array}$} & \multicolumn{2}{|c|}{ 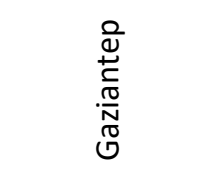 } & \multicolumn{4}{|c|}{$\frac{.5}{\frac{5}{0}}$} & \multicolumn{2}{|c|}{ 涪 } & \multicolumn{2}{|c|}{ 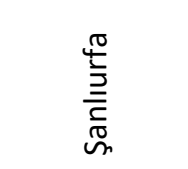 } & \multicolumn{2}{|c|}{$\begin{array}{l}\frac{y}{\sqrt{0}} \\
\frac{5}{5} \\
\overline{\omega n}\end{array}$} & \multicolumn{2}{|c|}{ 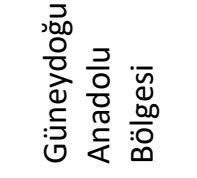 } & \multicolumn{2}{|c|}{ 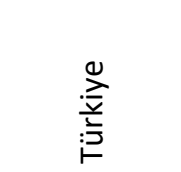 } \\
\hline & 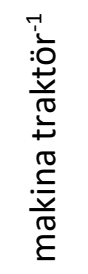 & 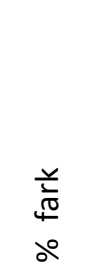 & 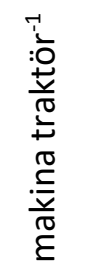 & 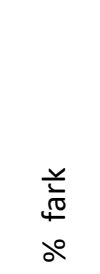 & 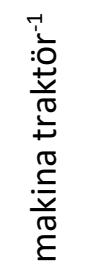 & 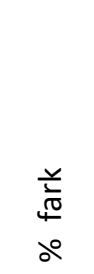 & 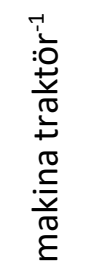 & 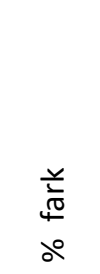 & 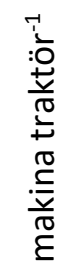 & $\begin{array}{l}\frac{y}{\frac{1}{\sigma}} \\
\frac{0}{0} \\
\text { مᄋ }\end{array}$ & 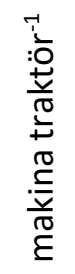 & 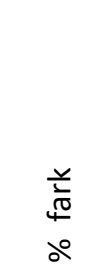 & 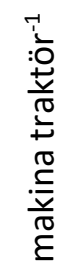 & 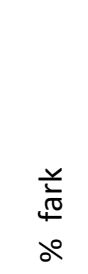 & 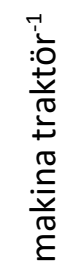 & 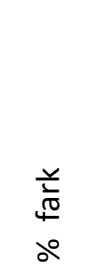 & 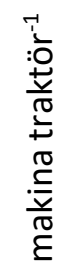 & 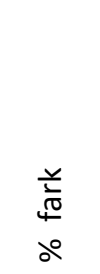 & 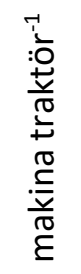 & $\begin{array}{l}\frac{2}{\frac{1}{\pi}} \\
\text { d0 } \\
\text { مᄋ }\end{array}$ & 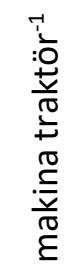 & 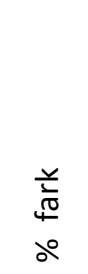 \\
\hline 2010 & 4.15 & & 5.88 & & 6.37 & & 3.90 & & 6.04 & & 4.82 & & 3.88 & & 5.94 & & 3.43 & & 5.04 & & 5.18 & \\
\hline 2011 & 4.30 & 3.68 & 5.79 & -1.51 & 6.82 & 7.17 & 3.93 & 0.81 & 5.96 & -1.37 & 4.79 & -0.60 & 3.70 & -4.57 & 6.00 & 0.98 & 3.26 & -4.79 & 5.17 & 2.51 & 5.14 & -0.78 \\
\hline 2012 & 4.11 & -4.39 & 6.44 & 11.23 & 6.81 & -0.10 & 3.76 & -4.21 & 5.88 & -1.21 & 4.97 & 3.71 & 3.54 & -4.38 & 5.87 & -2.11 & 3.10 & -4.93 & 5.00 & -3.40 & 5.01 & -2.59 \\
\hline 2013 & 4.28 & 4.08 & 6.47 & 0.39 & 6.80 & -0.28 & 3.80 & 1.00 & 5.89 & 0.08 & 4.78 & -3.98 & 3.86 & 8.94 & 5.87 & -0.02 & 3.06 & -1.46 & 5.03 & 0.60 & 4.91 & -2.04 \\
\hline 2014 & 4.16 & -2.92 & 7.38 & 14.19 & 6.95 & 2.31 & 3.80 & 0.00 & 5.92 & 0.47 & 5.36 & 12.34 & 3.67 & -4.80 & 5.93 & 1.00 & 3.04 & -0.43 & 5.09 & 1.18 & 4.84 & -1.45 \\
\hline 2015 & 4.06 & -2.30 & 7.51 & 1.73 & 7.10 & 2.09 & 3.81 & 0.33 & 6.05 & 2.24 & 5.39 & 0.44 & 3.66 & -0.26 & 5.93 & 0.00 & 3.08 & 1.18 & 5.10 & 0.20 & 4.84 & 0.00 \\
\hline 2016 & 4.08 & 0.41 & 7.83 & 4.24 & 7.09 & -0.10 & 3.83 & 0.46 & 6.27 & 3.61 & 5.49 & 1.96 & 3.62 & -1.10 & 5.99 & 1.07 & 3.09 & 0.50 & 5.14 & 0.78 & 4.85 & 0.21 \\
\hline 2017 & 4.10 & 0.67 & 8.04 & 2.64 & 7.18 & 1.19 & 3.85 & 0.42 & 6.20 & -1.07 & 5.17 & -5.86 & 3.71 & 2.28 & 5.93 & -1.06 & 3.13 & 1.22 & 5.13 & -0.19 & 4.82 & -0.62 \\
\hline 2018 & 4.16 & 1.34 & 7.77 & -3.36 & 6.95 & -3.19 & 3.83 & -0.47 & 6.30 & 1.67 & 5.09 & -1.68 & 3.35 & -9.71 & 5.93 & 0.03 & 3.34 & 6.66 & 5.09 & -0.79 & 4.80 & -0.42 \\
\hline 2019 & 3.90 & -6.19 & 7.80 & 0.38 & 6.85 & -1.41 & 3.84 & 0.29 & 6.44 & 2.23 & 5.16 & 1.38 & 3.34 & -0.08 & 5.84 & -1.49 & 4.47 & 33.87 & 5.04 & -0.99 & 4.78 & -0.42 \\
\hline Ort & & -0.62 & & 3.33 & & 0.85 & & -0.15 & & 0.74 & & 0.86 & & -1.52 & & -0.18 & & 3.54 & & -0.01 & & -0.90 \\
\hline
\end{tabular}




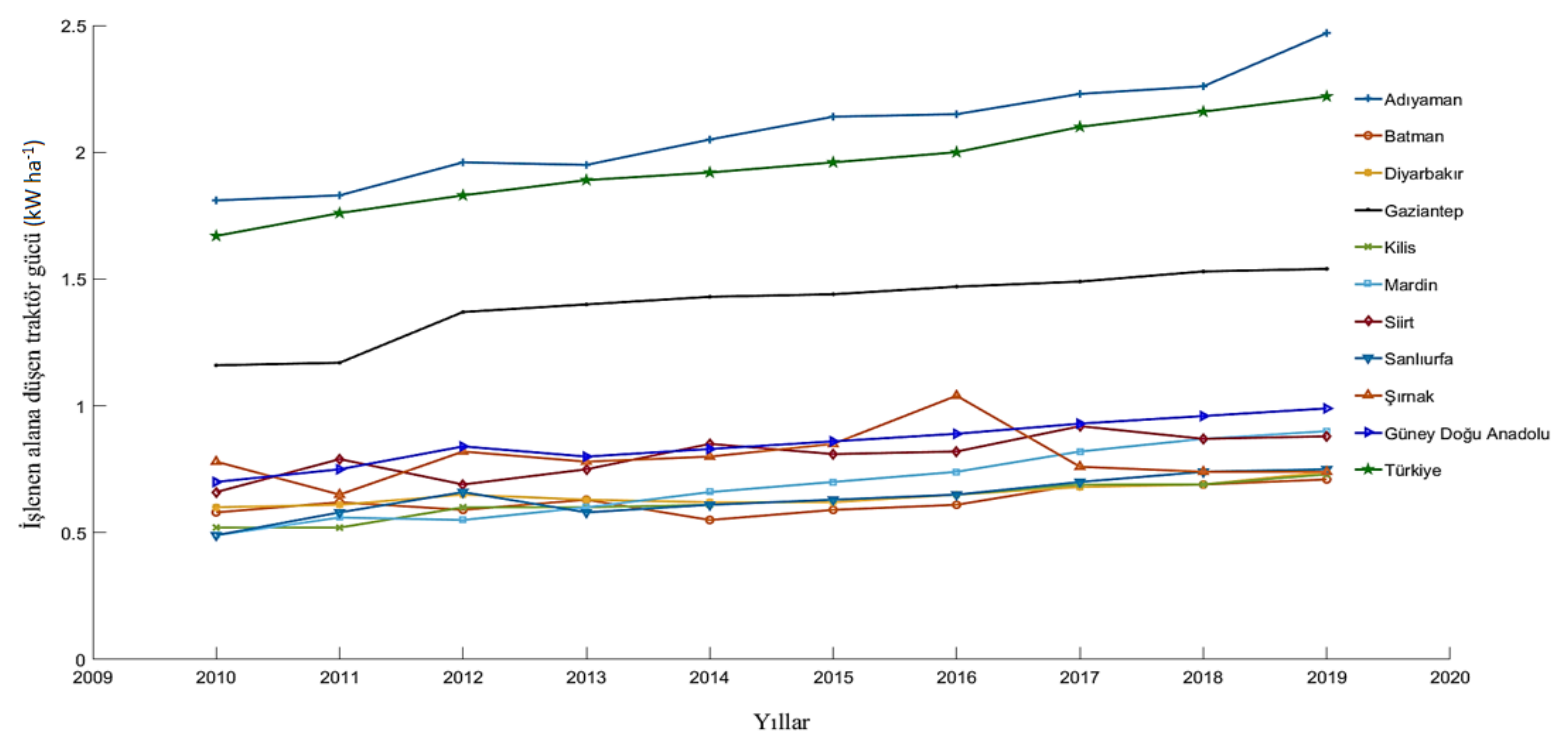

Şekil 1. Güneydoğu Anadolu Bölgesi illerinin 2010-2019 yıllarında işlenen alana düşen traktör gücü (kW ha ${ }^{-1}$ ) Figure 1. Tractor power per unit cultivated area $\left(\mathrm{kW} \mathrm{ha}^{-1}\right)$ of the Southeastern Anatolia Region provinces between 2010-2019

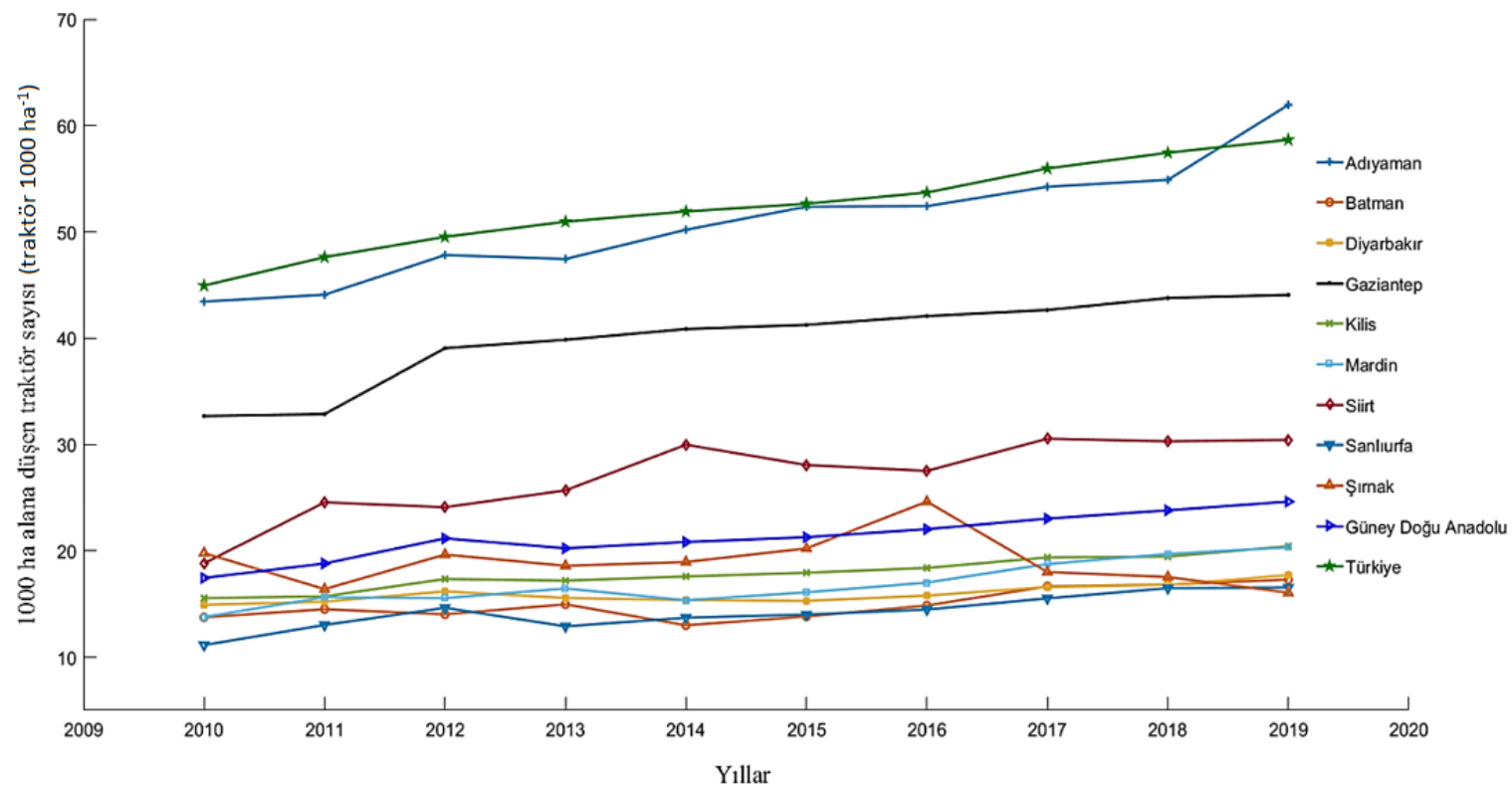

Şekil 2. Güneydoğu Anadolu Bölgesi illerinin 2010-2019 yıllarında 1000 ha alana düşen traktör sayısı (traktör 1000 ha $^{-1}$ )

Figure 2. Number of tractors per 1000 ha areas (tractor $1000 \mathrm{ha}^{-1}$ ) of the Southeastern Anatolia Region provinces between 2010-2019 


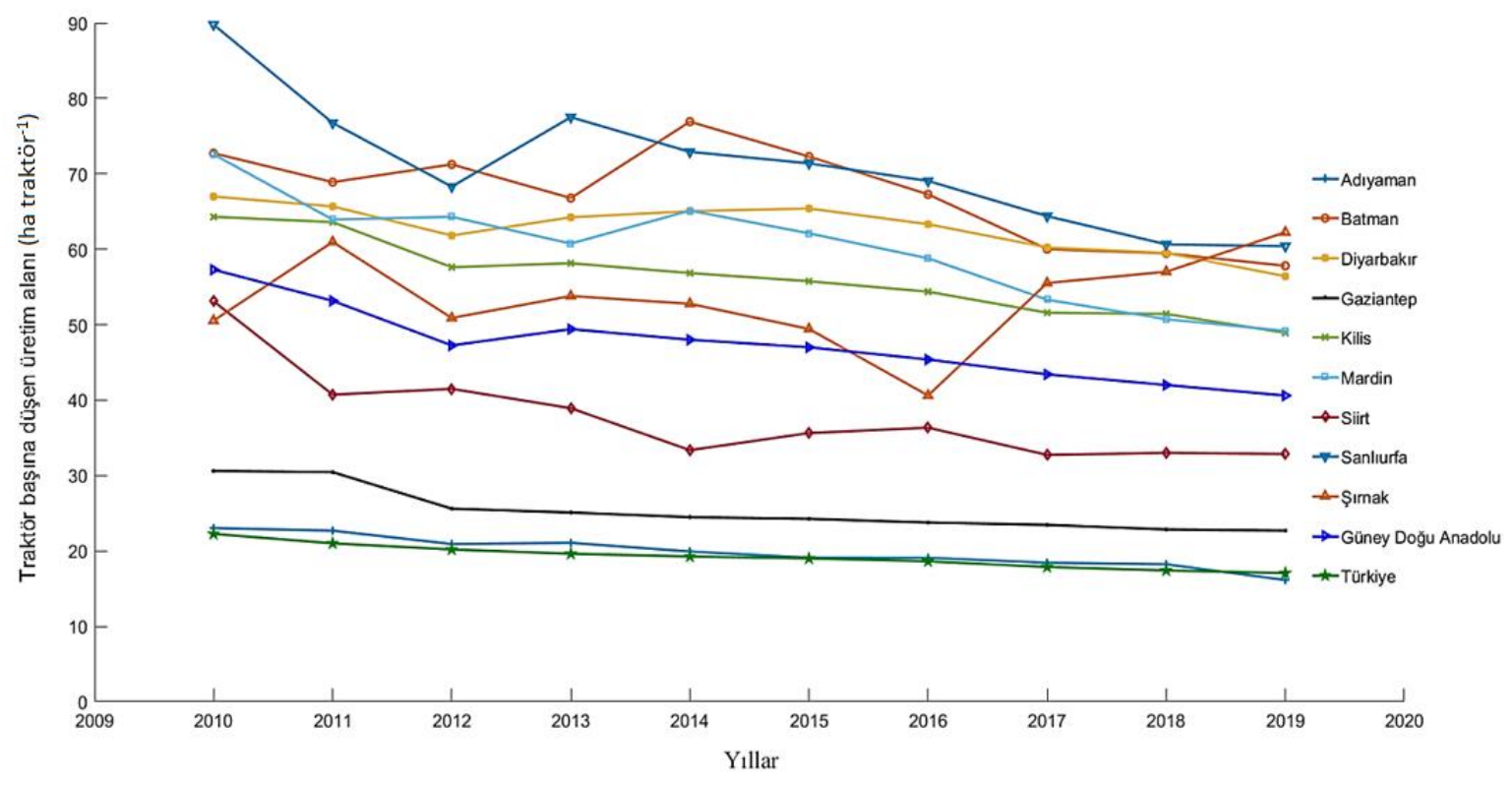

Şekil 3. Güneydoğu Anadolu Bölgesi illerinin 2010-2019 yıllarında traktör başına düşen üretim alanı (ha traktör ${ }^{-1}$ ) Figure 3. Production area per tractor (ha tractor ${ }^{-1}$ ) of the Southeastern Anatolia Region provinces between 2010-2019

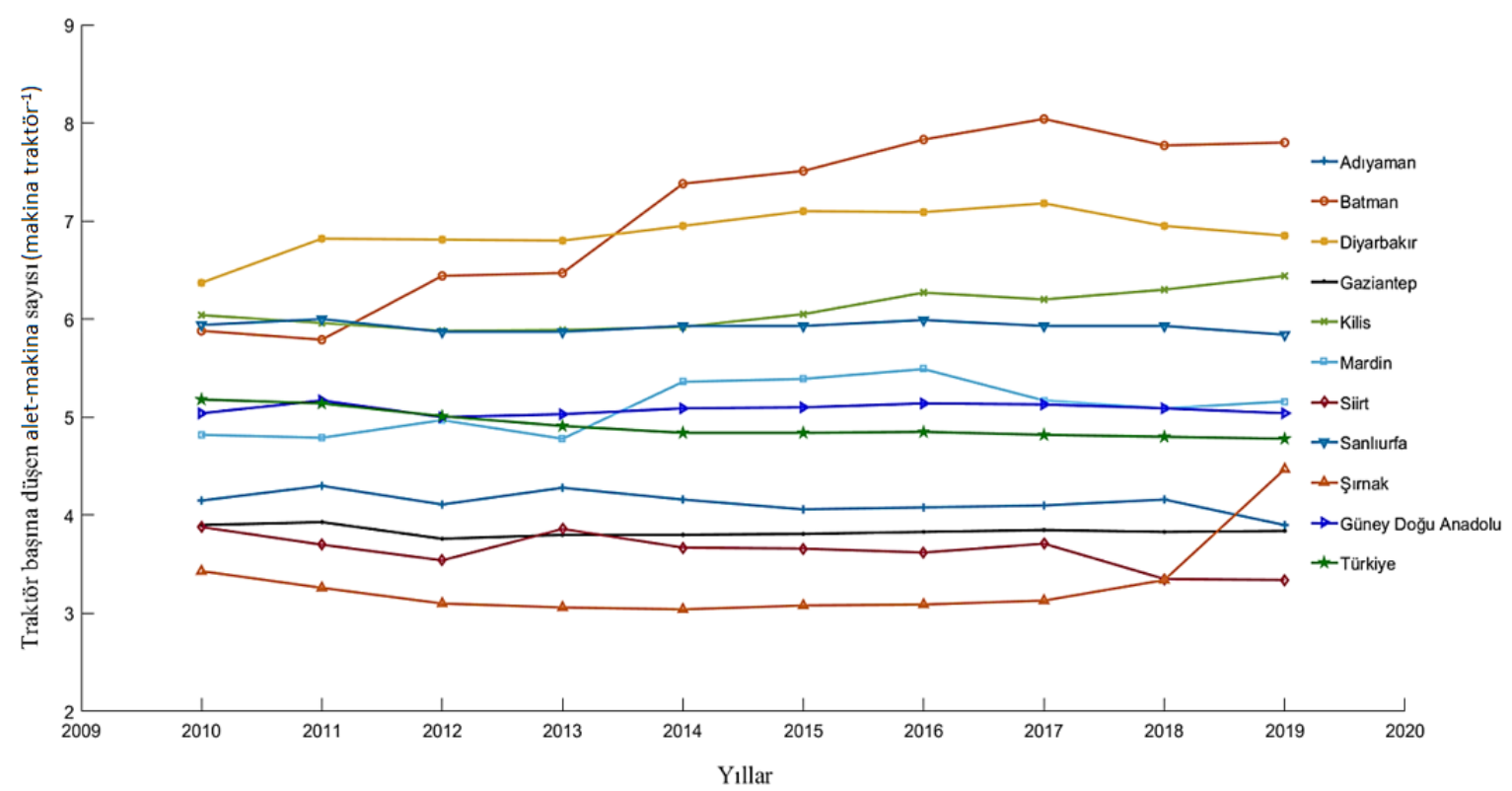

Şekil 4. Güneydoğu Anadolu Bölgesi illerinin 2010-2019 yıllarında traktör başına düşen alet-makina sayısı (makina traktör $\left.{ }^{-1}\right)$

Figure 4. Number of equipment-machine per tractor (machine tractor ${ }^{-1}$ ) of the Southeastern Anatolia Region provinces between 2010-2019 
Çizelge 13. Güneydoğu Anadolu Bölgesi illerinin 2020-2030 yıllarında trend analizi ile belirlenen işlenen alana düşen traktör gücü $\left(\mathrm{kW}\right.$ ha $\left.{ }^{-1}\right)$ değerleri Table 13. Tractor power per unit cultivated area $\left(\mathrm{kW} \mathrm{ha}^{-1}\right)$ values of the Southeastern Anatolia Region provinces for the years 2020-2030 determined by trend analysis

\begin{tabular}{|c|c|c|c|c|c|c|c|c|c|c|c|c|c|c|c|c|c|c|c|c|c|c|}
\hline & $\begin{array}{l}5 \\
\varepsilon \\
z\end{array}$ & & 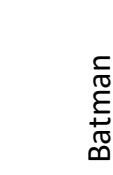 & & $\begin{array}{l}\frac{2}{\frac{2}{\pi}} \\
\frac{0}{2} \\
\frac{2}{\pi} \\
\frac{2}{0}\end{array}$ & & 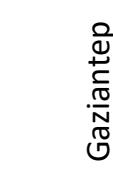 & & 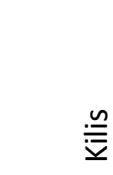 & & $\begin{array}{l}\frac{5}{0} \\
\frac{\pi}{\sqrt{0}} \\
\sum\end{array}$ & & : & & 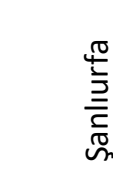 & & $\begin{array}{l}\frac{\mathrm{v}}{\mathrm{D}} \\
\frac{\mathrm{S}}{\mathrm{n}}\end{array}$ & & 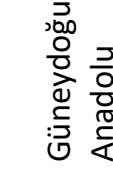 & $\begin{array}{l}\overline{\bar{y}} \\
\stackrel{0}{00} \\
\overline{0}\end{array}$ & 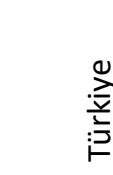 & \\
\hline$\frac{\frac{1}{\bar{t}}}{\overline{\bar{亠}}}$ & 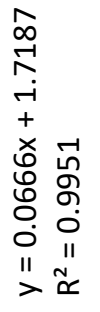 & 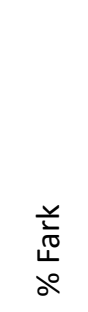 & 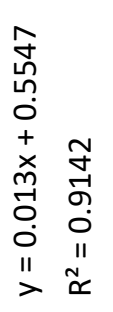 & 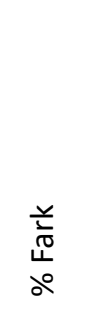 & 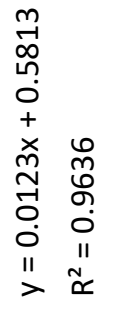 & 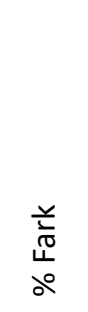 & 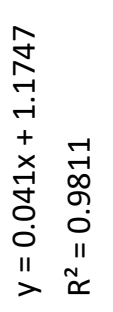 & 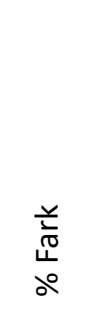 & 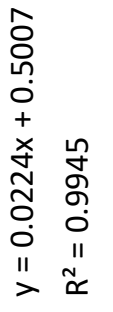 & 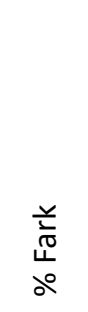 & 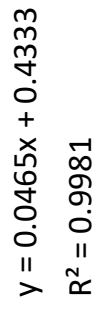 & 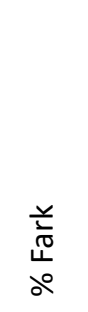 & 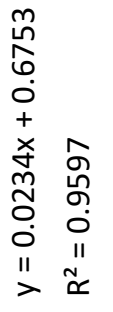 & 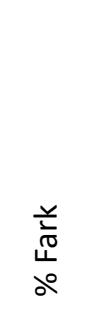 & 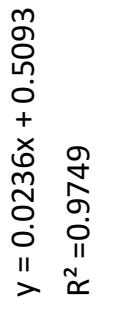 & 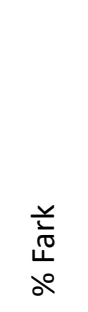 & 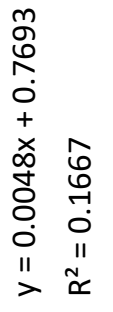 & 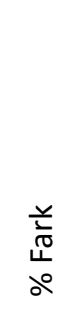 & 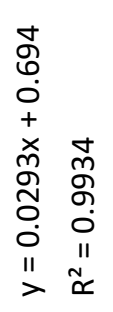 & 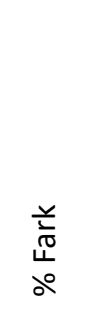 & 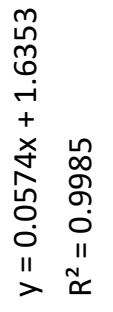 & 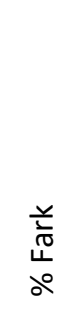 \\
\hline 2020 & 2.45 & & 0.70 & & 0.72 & & 1.63 & & 0.75 & & 0.94 & & 0.93 & & 0.77 & & 0.82 & & 1.02 & & 2.27 & \\
\hline 2021 & 2.52 & 2.78 & 0.71 & 1.41 & 0.73 & 1.37 & 1.67 & 2.40 & 0.77 & 2.60 & 0.99 & 5.05 & 0.96 & 3.12 & 0.79 & 2.53 & 0.83 & 1.20 & 1.05 & 2.86 & 2.32 & 2.16 \\
\hline 2022 & 2.58 & 2.33 & 0.72 & 1.39 & 0.74 & 1.35 & 1.71 & 2.34 & 0.79 & 2.53 & 1.04 & 4.81 & 0.98 & 2.04 & 0.82 & 3.66 & 0.83 & 0.00 & 1.07 & 1.87 & 2.38 & 2.52 \\
\hline 2023 & 2.65 & 2.64 & 0.74 & 2.70 & 0.75 & 1.33 & 1.75 & 2.29 & 0.81 & 2.47 & 1.08 & 3.70 & 1.00 & 2.00 & 0.84 & 2.38 & 0.84 & 1.19 & 1.1 & 2.73 & 2.44 & 2.46 \\
\hline 2024 & 2.72 & 2.57 & 0.75 & 1.33 & 0.77 & 2.60 & 1.79 & 2.23 & 0.84 & 3.57 & 1.13 & 4.42 & 1.03 & 2.91 & 0.86 & 2.33 & 0.84 & 0.00 & 1.13 & 2.65 & 2.5 & 2.40 \\
\hline 2025 & 2.78 & 2.16 & 0.76 & 1.32 & 0.78 & 1.28 & 1.83 & 2.19 & 0.86 & 2.33 & 1.18 & 4.24 & 1.05 & 1.90 & 0.89 & 3.37 & 0.85 & 1.18 & 1.16 & 2.59 & 2.55 & 1.96 \\
\hline 2026 & 2.85 & 2.46 & 0.78 & 2.56 & 0.79 & 1.27 & 1.87 & 2.14 & 0.88 & 2.27 & 1.22 & 3.28 & 1.07 & 1.87 & 0.91 & 2.20 & 0.85 & 0.00 & 1.19 & 2.52 & 2.61 & 2.30 \\
\hline 2027 & 2.92 & 2.40 & 0.79 & 1.27 & 0.80 & 1.25 & 1.91 & 2.09 & 0.9 & 2.22 & 1.27 & 3.94 & 1.10 & 2.73 & 0.93 & 2.15 & 0.86 & 1.16 & 1.22 & 2.46 & 2.67 & 2.25 \\
\hline 2028 & 2.98 & 2.01 & 0.80 & 1.25 & 0.82 & 2.44 & 1.95 & 2.05 & 0.93 & 3.23 & 1.32 & 3.79 & 1.12 & 1.79 & 0.96 & 3.12 & 0.86 & 0.00 & 1.25 & 2.40 & 2.73 & 2.20 \\
\hline 2029 & 3.05 & 2.30 & 0.81 & 1.23 & 0.83 & 1.20 & 1.99 & 2.01 & 0.95 & 2.11 & 1.36 & 2.94 & 1.14 & 1.75 & 0.98 & 2.04 & 0.87 & 1.15 & 1.28 & 2.34 & 2.78 & 1.80 \\
\hline 2030 & 3.12 & 2.24 & 0.83 & 2.41 & 0.84 & 1.19 & 2.04 & 2.45 & 0.97 & 2.06 & 1.41 & 3.55 & 1.17 & 2.56 & 1.00 & 2.00 & 0.87 & 0.00 & 1.31 & 2.29 & 2.84 & 2.11 \\
\hline Ort & & 2.39 & & 1.69 & & 1.53 & & 2.22 & & 2.54 & & 3.97 & & 2.27 & & 2.58 & & 0.59 & & 2.47 & & 2.22 \\
\hline
\end{tabular}




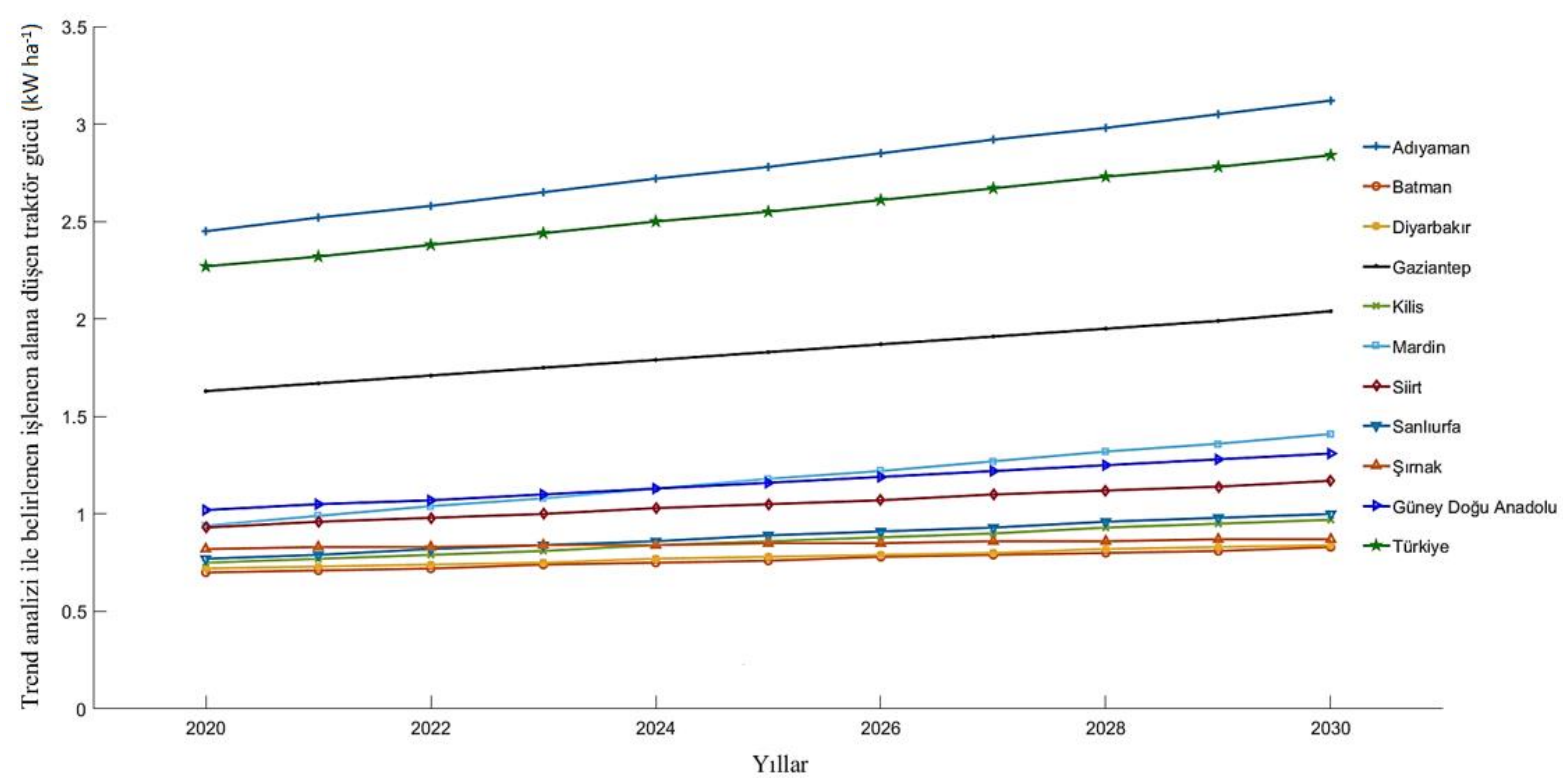

Şekil 5. Güneydoğu Anadolu Bölgesi illerinin 2020-2030 yıllarında trend analizi ile belirlenen işlenen alana düşen traktör gücü $\left(\mathrm{kW} \mathrm{ha}^{-1}\right)$ değerleri

Figure 5. Tractor power per unit cultivated area $\left(\mathrm{kW} \mathrm{ha}^{-1}\right)$ values of the Southeastern Anatolia Region provinces for the years 2020-2030 determined by trend analysis

\section{SONUÇ ve ÖNERILER}

Çalışma, Güneydoğu Anadolu Bölgesi'nin tarımsal mekanizasyon planlamalarında; optimum işletme büyüklüğü ve traktör boyutlarının (güç ve sayı) belirlenmesi, üretim karlılığı, rekabet gücü vb. konularda katkı sağlayabilecektir. Bölgenin iller bazında 2010-2019 yıllarındaki tarımsal mekanizasyon düzeyi gösterge değerleri ( $\mathrm{kW} \mathrm{ha}^{-1}$, traktör $1000 \mathrm{ha}^{-1}$, ha traktör ${ }^{-1}$, makina traktö $\left.{ }^{-1}\right)$ belirlenmiş ve gelecek yıllar (2020-2030) için mekanizasyon düzeyi göstergelerinden $\mathrm{kW} \mathrm{ha}^{-1}$ değeri trend analizi ile belirlenmiş ve değerlendirilmiştir. Veriler (işlenen tarım alanları, traktör sayıları ve güç değerleri, tarım alet-makina sayıları) Türkiye İstatistik Kurumundan alınmış ve yıllar bazında bölge illerinin, bölge genelinin ve Türkiye genelinin mekanizasyon düzeyi gösterge değerleri hesaplanmıştır.

Güneydoğu Anadolu Bölgesi genelinde yıllara göre kW $\mathrm{ha}^{-1}$, traktör $1000 \mathrm{ha}^{-1}$ gösterge değerleri artış (0.70-0.99 kW ha-1; 17.45-24.63 traktör $\left.1000 \mathrm{ha}^{-1}\right)$, ha traktör ${ }^{-1}$ ve makina traktör ${ }^{-1}$ gösterge değerleri ise azalma (57.2940.60 ha traktör-1; 5.17-5.04 makina traktö $r^{-1}$ ) göstermiştir. kW ha ${ }^{-1}$ değeri bölge genelinde; geçmiş on yılda (2010-2019) ortalama \%3.70 artış göstererek 0.70$0.99 \mathrm{~kW} \mathrm{ha}^{-1}$ olduğu, gelecek on bir yılda (2020-2030) ise ortalama \%2.47 artış olacağı ve bu değerin de Türkiye ortalamasının (\%2.22) üzerinde gerçekleşeceği, 2025 yılı için $1.16 \mathrm{~kW} \mathrm{ha}^{-1}$ ve 2030 yılı için ise $1.31 \mathrm{~kW} \mathrm{ha}^{-1}$ olarak belirlenmiştir. Traktör $1000 \mathrm{ha}^{-1}$ değeri; bölge genelinde geçmiş on yılda ortalama \%3.68 artış göstermiş ve bu değer Türkiye ortalamasından (\%2.91) daha yüksek olmuştur. ha traktör-1 değeri, bölge genelinde azalmış (\%3.99) ve bu azalma Türkiye'nin ortalama değerinden daha yüksek (-\%3.01) olmuştur. ha traktör ${ }^{-1}$ değerindeki azalma, mekanizasyon düzeyinin artış gösterdiği veya iyileşme sağladığını göstermektedir. Makina traktör ${ }^{-1}$ gösterge değeri bölge genelinde azalmıştır. Sonuç olarak, Güneydoğu Anadolu Bölgesinde mekanizasyon düzeyi yıllara göre iyileşme sağlamakta, ancak bu düzeyin iyileşme hızı AB'ye $\left(6 \mathrm{~kW} \mathrm{ha-1}, 11.30\right.$ ha traktör ${ }^{-1}, 89$ traktör $1000 \mathrm{ha}^{-1}, 10$ makina traktör-1 $^{-1}$ göre çok düşük olmaktadır. Bölgedeki tarım alanlarındaki artış veya azalmalar ekim alanlarının değişiminden kaynaklanmaktadır.

\section{ÖZET}

Amaç: Tarım işletmelerinde daha sağlıklı üretim planlamalarının yapılması, verimliliğin arttırılması ve geleceğe yönelik projeksiyonlar oluşturulması için bölgenin mekanizasyon düzeyinin belirlenmesi ve irdelenmesi amaçlanmıştır.

Yöntem ve Bulgular: Bu çalışmada, Türkiye'nin önemli bir tarım bölgesi olan Güneydoğu Anadolu Bölgesi'nin iller bazında mekanizasyon düzeyi gösterge değerleri (kW ha- ${ }^{-1}$, traktör sayısı 1000 ha $^{-1}$, ha traktör ${ }^{-1}$, makina traktör $\left.{ }^{-1}\right)$, 2010-2019 yılları için belirlenmiş ve 2020-2030 yılları için ise $\mathrm{kW} \mathrm{ha-1}$ değeri trend analizi yardımıyla tahmin edilmiş ve değerlendirilmiştir. Veriler, Türkiye İstatistik Kurumundan alınmıştır. 
Genel Yorum: Bölge genelinde yıllara göre $\mathrm{kW} \mathrm{ha-1}$, traktör $1000 \mathrm{ha}^{-1}$ gösterge değerleri artmış (0.70-0.99 kW ha ${ }^{-1} ; 17.45-24.63$ traktör 1000 ha $^{-1}$ ), ha traktör ${ }^{-1}$ ve makina traktör-1 gösterge değerleri ise azalmıştır (57.2940.60 ha traktör ${ }^{-1}$; 5.17-5.04 makina traktör $\left.{ }^{-1}\right)$. kW ha ${ }^{-1}$ değeri; en yüksek Adıyaman ilinde (1.81-2.47 kW ha-1), en düşük ise Diyarbakır ilinde (0.60-0.74 kW ha-1) gerçekleşmiş ve bölge genelinde on yılda ortalama \%3.70 artış göstererek 0.70-0.99 kW ha-1 olmuştur. kW ha-1 gösterge değeri; bölge genelinde 2020-2030 yıllarının ortalama artış değerinin \%2.47 olması tahmin edilmiş ve bu değerin de Türkiye ortalamasının (\%2.22) üzerinde gerçekleştiği görülmüştür. $\mathrm{kW} \mathrm{ha}^{-1}$ değeri; bölge geneli için 2020 yılında 1.02, 2025 yılında 1.16 ve 2030 yılında $1.31 \mathrm{olması}$ tahmin edilmektedir. Bölgede mekanizasyon düzeyinin yıllara göre iyileşme sağladığı, ancak bu düzeyin iyileşme hızının düşük olduğu belirlenmiştir.

Çalışmanın Önemi ve Etkisi: Tarımsal mekanizasyon düzeyinin bölgesel/iller bazında kapsamlı olarak güncel verilerle ortaya konulması, tarımsal kalkınma planlarına katkı sağlayarak geleceğe yönelik doğru kararların alınmasını sağlayabilecektir. Böylece tarım işletmelerinin; daha sağlıklı üretim planlaması yapılabilecek, işletmeye optimum traktör ve makina seçimi gerçekleştirilebilecek, verimlilik arttırılabilecek ve geleceğe yönelik projeksiyonlar oluşturulabilecektir.

Anahtar Kelimeler: Tarımsal mekanizasyon düzeyi, Güneydoğu Anadolu Bölgesi, Trend analizi.

\section{ÇIKAR ÇATIŞMA BEYANI}

Makale yazarları aralarında herhangi bir çıkar çatışması olmadığını beyan ederler.

\section{ARAŞTIRMACILARIN KATKI ORANI BEYANI}

Yazarlar çalışmaya eşit oranda katkı sağlamış olduklarını beyan eder.

\section{KAYNAKLAR}

Abdikoğlu Di (2019) Trakya Bölgesinde Tarımsal Mekanizasyon Düzeyinin illere Göre Belirlenmesi. Kahramanmaraş Sütçü İmam Üniversitesi Tarım ve Doğa Dergisi 22(6): 865-871.

Allen RGD (1964) Statics for Economists, Mc-Millan, UK. pp 133-152.

Altıkat S, Çelik A (2009) Erzurum ilinin Mekanizasyon Özellikleri. Atatürk Üniversitesi Ziraat Fakültesi Dergisi 40(2): 57-70.
Altuntaş E (2016) Türkiye'nin Tarımsal Mekanizasyon Düzeyinin Coğrafik Bölgeler Açısından Değerlendirilmesi. Türk Tarım - Gıda Bilim ve Teknoloji Dergisi 4(12): 1157-1164.

Anonim (2020a) T.C. Kalkınma Bakanlığı Güneydoğu Anadolu Projesi Kalkınma İdaresi Başkanlığı. http://www.gap.gov.tr/tarim-sayfa-15.html

Anonim (2020b) Türkiye İstatistik Kurumu. Bitkisel Üretim İstatistikleri. http://www.tuik.gov.tr (Erişim tarihi: Şubat-Nisan 2020).

Anonim (2020c) Türkiye İstatistik Kurumu. Tarımsal Alet ve Makine İstatistikleri. http://www.tuik.gov.tr (Erişim tarihi: Ocak-Mart 2020).

Aybek A, Boz I (2006) The Influence of Various Factors on Tractor Selection. Agricultural Mechanization in Asia, Africa and Latin America (AMA), 37(2): 58-61. The Shin-Norinsha Co., Ltd. and The International Farm Mechanization Research Service, Tokyo-Japan.

Bayram M, Altuntaş E (2016) Tokat Ili'nin 2003 ve 2013 Yılları için Mekanizasyon Özelliklerindeki Değişiminin Incelenmesi. Tarım Makinaları Bilimi Dergisi 12(3): 213-220.

Benek S (2006) Şanlıurfa ilinin tarımsal yapısı, sorunları ve çözüm önerileri. Coğrafi Bilimler Dergisi 4(1): 6791.

Bilim C, Korucu T, Semerci T (2014) Gaziantep ilinin Tarımsal Mekanizasyon Özellikleri. Kahramanmaraş Sütçü İmam Üniversitesi Doğa Bilimleri Dergisi 17(2): 14-23.

Bozkurt M, Aybek A (2016) Şanlıurfa ili Harran Ovasının Tarımsal Yapı ve Mekanizasyon Özellikleri. Kahramanmaraş Sütçü İmam Üniversitesi Doğa Bilimleri Dergisi 19(3): 319-331.

Bölükoğlu $H$, Tüzün AM, Mutlu $N$, Yenigün R, Pekcan $\mathrm{I}$ (2001) Gap Bölgesinde Ortak Makina Kullanım Organizasyonlarının Önemi ve Yönetimi. Tarımsal Mekanizasyon 20. Ulusal Kongresi, 13-15 Eylül, Şanlıurfa, 598-604.

Dağ A (2018) Mardin îli ve îlçelerinde Tarımsal Mekanizasyon Düzeyinin ve Traktörlerin Durumunun Belirlenmesi. Yüksek Lisans Tezi, Tekirdağ Namık Kemal Üniversitesi, Fen Bil. Ens., Biyosistem Mühendisliği ABD, 38s.

Evcim HÜ, Ulusoy E, Gülsoylu E, Tekin AB (2010) Tarımsal mekanizasyon durumu sorunları ve çözüm önerileri. Türkiye Ziraat Mühendisleri VII. Teknik Kongresi, 11 15 Ocak, Ankara, 989-1007.

Evcim HÜ, Tekin AB, Gülsoylu E, Demir V, Yürdem H, Güler H, Bilgen H, Alayunt F, Evrenosoğlu M (2015) Tarımsal Mekanizasyon Durumu, Sorunları ve Çözüm Önerileri. Türkiye Ziraat Mühendisliği VIII. Teknik Kongresi, 12-16 Ocak, Ankara, 1080-1106. 
Gökdoğan O (2012) Türkiye ve Avrupa Birliği'nin Tarımsal Mekanizasyon Düzeyi Göstergelerinin Karşılaştırılması. Adnan Menderes Üniversitesi Ziraat Fakültesi Dergisi 9(2): 1-4.

Güler I, Yaylagül H (1997) Harran Ovası İşletmelerinde Makina Kullanma Durumu Ve Geliştirme Olanakları Üzerine Bir Araştırma. Atatürk Üniversitesi Ziraat Fakültesi Dergisi 28(3): 354-368.

Gürsoy S (2012) Güneydoğu Anadolu Bölgesinde Tarımsal Üretimin Gelişmesinde Mekanizasyonun Rolü. Batman Üniversitesi Yaşam Bilimleri Dergisi 1(2): 339-346.

Gürsoy S (2013) Batman illinin Tarımsal Mekanizasyon Düzeyinin İlçeler Bazında Değerlendirilmesi. Batman Üniversitesi Yaşam Bilimleri Dergisi 3(2): 146-158.

Illeri MS (2010) Tarımsal Mekanizasyon Sektör Raporu, TARMAKBIR, Ankara.

Işık A (1988) Sulu Tarımda Kullanılan Mekanizasyon Araçlarının Optimum Makina ve Güç Seçimine Yönelik İşletme Değerlerinin Belirlenmesi ve Uygun Seçim Modellerinin Oluşturulması Üzerinde Bir Araştırma. Doktora Tezi, Çukurova Üniversitesi, Fen Bil. Ens., Tarımsal Mekanizasyon ABD, 210s.

Işık A, Atun i (1998) Agricultural Structure and Mechanisation Characteristics of the ŞanlıurfaHarran Plain. Turkish Agriculture and Forrestry Bulletin 22(2): 151-160.

Işık A, Akıncı I, Sabancı A (1995) GAP Bölgesine Uygun Tarım Makinaları Seçimi Ve 2000'li Yıllarda Park Talebi. Tarımsal Mekanizasyon 16. Ulusal Kongresi, 57 Eylül, Bursa, 45-54.

Koçtürk D, Onurbaş Avcıoğlu A (2007) Türkiye'de bölgelere ve illere göre tarımsal mekanizasyon düzeyinin belirlenmesi. Tarım Makinaları Bilimi Dergisi 3(1): 17-24.

Korucu T, Aybek A, Sivrikaya F (2015) Türkiye'nin Tarım Bölgeleri Bazında Mekanizasyon Düzeyinin Yersel Değişim Haritalarının Oluşturulması ve Değerlendirilmesi. Kahramanmaraş Sütçü İmam Üniversitesi Doğa Bilimleri Dergisi 18(4): 77-90.

Landers A (2000) Resource management. Farm Machinery: Selection, Investmen and Management. Farming pres, UK. pp 149.

Malaslı MZ, Çelik A, Çelik Ş (2015) Güneydoğu Anadolu Bölgesi'nin Toprak İşleme Alet Ve Makinaları Projeksiyonunun Regresyon Analizi Yöntemiyle Belirlenmesi. Türk Tarım ve Doğa Bilimleri Dergisi 2(1): 126-132.

Maxwell SE, Delaney HD (2004) Designing experiments and analyzing data: A model comparison perspective (2nd ed.). Mahwah, NJ: Lawrence Erlbaum Associates.
Newbold P (2000) İşletme ve İktisat için İstatistik, (çev. Ümit Şenesen). Literatür Yayıncılık İstanbul. 777-785 $\mathrm{s}$.

Özel R (2015) Harran Ovasında Pamuk Hasadında Makina Kullanımı. Harran Tarım ve Gıda Bilimleri Dergisi 17(1): 7-13.

Özpınar S (2001) Marmara Bölgesi'nin Tarımsal Mekanizasyon Özelliklerinin Belirlenmesi. Tarımsal Mekanizasyon 20. Ulusal Kongresi Bildiri Kitabı, 13-15 Eylül, Şanlıurfa, 41-46.

Polat R, Sağlam R (2001) GAP Bölgesinin Mekanizasyon Durumu ve Sorunları. Tarımsal Mekanizasyon 20. Ulusal Kongresi Bildiri Kitabı, 13-15 Eylül, Şanlıurfa 617-621.

Ruiyin H, Wenqingv Y, Yadong Z, Van Sonsbeek G (1999) Improving management system of agricultural machinery in jiangsu. Proceedings of 99 International Conference on Agri. Engine, Beijing, China, pp I-42-45.

Sağlam C, Çevik M (2014) Şanlıurfa'daki Çiftçilerin Traktör Satın Alma Davranışlarına Etkili Faktörlerin Belirlenmesi. Harran Tarım ve Gıda Bilimleri Dergisi 16(1): 1-8.

Sağlam R, Şen Ş, Tobi i (2014) Şanlıurfa Bozova-Yaylak Pompaj Sulama Alanında Sulama Öncesi Ve Sonrası Çiftçi Düzeyinde Tarım Makinalarında Ortak Makine Kullanım Eğilimlerinin Araştırılması. Harran Tarım Ve Gıda Bilimleri Dergisi 15(3): 45-54.

Say SM, Sabancı A, Başçetinçelik A, Özgüven F, Öztürk HH (2010) Tarım Makinaları 1. Nobel Kitapevi, Adana.

Sayın C, Gülçubuk B, Bozoğlu M, Koçak A, Özalp A, Sav O, İlbasmış E, Ceylan M (2015) Türkiye'de Tarımsal Yapıda Değişim Ve İzlenen Politikalar. Türkiye Ziraat Mühendisliği VIII. Teknik Kongresi, 12-16 Ocak, Ankara, 9-32.

Semerci A, Özer S (2011) Türkiye'de Ayçiçeği Ekim Alanı, Üretim Miktarı Ve Verim Değerinde Olası Değişimler. Tekirdağ Ziraat Fakültesi Dergisi 8(3): 46-52.

Sessiz A, Turgut MM, Pekitkan FG, Esgici R (2006) Diyarbakır ilindeki tarım işletmelerinin tarımsal yapı ve mekanizasyon özellikleri. Tarım Makinaları Bilimi Dergisi 2(1): 87-93.

Solmaz M, Saltuk B, Baran MF (2019) Siirt Tarımında Alet Ve Makina Kullanım Projeksiyonu. ISPEC Uluslararası Tarım ve Kırsal Kalkınma Kongresi, 10-12 Haziran, Siirt, 71-79.

Ulusoy E, Türkay B, Has M, Dönder Ö, ileri S, Canoğlu S, Önal Ş, Bilgen H, Demir V, Yazgı A (2020) Tarım Makinaları Sanayinde Mevcut Durum ve Gelecek. Türkiye Ziraat Mühendisliği IX. Teknik Kongresi, 13-17 Ocak, Ankara, 233-256. 
Vurarak Y, Sağlam C, Çıkman A (2007) Şanlıurfa İlinde Bulunan Büyük Tarım İşletmelerinin Mekanizasyon Düzeyi. Tarımsal Mekanizasyon 24. Ulusal Kongresi, 5-6 Eylül, Kahramanmaraş, 98-107.

Witt SF, Witt CA (1992) Modeling and Forecasting Demand in Tourism. Academic Press, London. pp 208. Yavuz H (2016) Hayvancılık Destekleme Politikalarının Tarımsal iş̧letmeler Açısından Değerlendirilmesi: Amasya İli Örneği. Yüksek Lisans Tezi , Gaziosmanpaşa Üniversitesi, Fen Bil. Ens., Tarım Ekonomisi ABD, $124 s$.
Yılmaz S, Sümer SK (2018) Güney Marmara Kalkınma Bölgesinin Tarımsal Mekanizasyon Düzeyinin Belirlenmesi. 2. Çanakkale Tarımı Sempozyumu, 7-9 Şubat, Çanakkale, 80-80. 